\title{
Hyaluronic acid fillers with cohesive polydensified matrix for soft-tissue augmentation and rejuvenation: a literature review
}

\author{
This article was published in the following Dove Press journal: \\ Clinical, Cosmetic and Investigational Dermatology \\ 8 September 2016 \\ Number of times this article has been viewed
}

\section{Adri D Prasetyo' \\ Welf Prager ${ }^{2}$ \\ Mark G Rubin ${ }^{3}$ \\ Ernesto A Moretti ${ }^{4}$ \\ Andreas Nikolis ${ }^{5}$}

'Rejuva Skin \& Beauty, Surabaya, Indonesia; ${ }^{2}$ Prager \& Partner, Hamburg, Germany; ${ }^{3}$ University of California, San Diego, CA, USA; ${ }^{4}$ Gamma Health Group, Sanatorio Los Arroyos, Santa Fe, Republic of Argentina; ${ }^{5}$ Victoria Park Clinical Research Centre, Westmount, QC, Canada
Correspondence: Adri D Prasetyo Rejuva Skin \& Beauty, Rich Palace C-8, Mayjen Sungkono I49-15I, Surabaya 60225 , Indonesia

Tel +628123270940

Fax +62315675550

Email adri_dermatology@yahoo.com
Background: Cohesive monophasic polydensified fillers show unique viscoelastic properties and variable density of hyaluronic acid, allowing for a homogeneous tissue integration and distribution of the material.

Objective: The aim of this paper was to review the clinical data regarding the performance, tolerability, and safety of the Belotero ${ }^{\circledR}$ fillers for soft-tissue augmentation and rejuvenation.

Methods: A literature search was performed up until May 31, 2015 to identify all relevant articles on Belotero ${ }^{\circledR}$ fillers (Basic/Balance, Hydro, Soft, Intense, Volume) and equivalent products (Esthélis ${ }^{\circledR}$, Mesolis $^{\circledR}$, Fortélis $^{\circledR}$, Modélis $^{\circledR}$ ).

Results: This comprehensive review included 26 papers. Findings from three randomized controlled trials showed a greater reduction in nasolabial fold severity with Belotero ${ }^{\circledR}$ Basic/ Balance than with collagen (at 8, 12, 16, and 24 weeks, $\mathrm{n}=118$ ) and Restylane ${ }^{\circledR}$ (at 4 weeks, $\mathrm{n}=40$ ), and higher patient satisfaction with Belotero ${ }^{\circledR}$ Intense than with Perlane ${ }^{\circledR}$ (at 2 weeks, $\mathrm{n}=20$ ). With Belotero ${ }^{\circledR}$ Basic/Balance, an improvement of at least 1 point on the severity scale can be expected in $\sim 80 \%$ of patients $1-6$ months after injection, with an effect still visible at $8-12$ months. Positive findings were also reported with Belotero ${ }^{\circledR}$ Volume (no reduction in hyaluronic acid volume at 12 months, as demonstrated by magnetic resonance imaging), Soft (improvement in the esthetic outcomes when used in a sequential approach), and Hydro (improvement in skin appearance in all patients). The most common adverse effects were mildto-moderate erythema, edema, and hematoma, most of which were temporary. There were no reports of Tyndall effect, nodules, granulomas, or tissue necrosis.

Conclusion: Clinical evidence indicates sustainable esthetic effects, good safety profile, and long-term tolerability of the Belotero ${ }^{\circledR}$ fillers, particularly Belotero ${ }^{\circledR}$ Basic/Balance and Intense. Keywords: $\mathrm{CPM}^{\circledR}$, dermal filler, facial lines, filling, nasolabial fold, wrinkle

\section{Introduction}

In recent years, injectable dermal fillers have challenged the use of more invasive esthetic surgical procedures. ${ }^{1-3}$ Based on a survey conducted by the International Society of Aesthetic Plastic Surgery, there were more than eleven million nonsurgical procedures performed worldwide in 2013, and more than three million involved resorbable fillers. ${ }^{4}$ Nonpermanent dermal fillers are mainly used for the filling of rhytides and folds, and the correction of soft-tissue loss caused by disease or age. ${ }^{5}$ 
They provide volume restoration, ${ }^{1-3}$ with minimal downtime, favorable safety profile, and rapid and reproducible results. ${ }^{6}$

The most commonly used dermal filler is hyaluronic acid (HA). ${ }^{7}$ According to the statistics of the American Society for Aesthetic Plastic Surgery, >1.6 million HA filler procedures were performed in 2014 in the US, making it the second most frequently used nonsurgical esthetic procedure after botulinum toxin.

HA, which is a naturally occurring biopolymer, is degraded by a family of enzymes called hyaluronidases. ${ }^{8}$ Various crosslinking techniques have been developed to prevent the rapid degradation of HA in the skin and provide long-term treatment effects. ${ }^{1,9,10}$ The crosslinking technology, the uniformity and size of the particles, and the HA concentration of the filler determine its viscoelastic properties, and therefore its clinical effect. ${ }^{5,11}$

The first HA dermal fillers on the market were non-cohesive biphasic fillers, characterized as crosslinked particles suspended in a non-crosslinked HA matrix acting as a lubricant. ${ }^{11,12}$ These products (eg, Restylane ${ }^{\circledR}$, Q-Med AB, Uppsala, Sweden, a wholly owned subsidiary of Galderma, Fort Worth, TX, USA; HA concentration $20 \mathrm{mg} / \mathrm{mL}$ ) are manufactured with nonanimal-stabilized hyaluronic acid $\left(\right.$ NASHA $\left.^{\circledR}\right)$ technology. ${ }^{13}$ A large variety of HA dermal fillers have since been designed. Monophasic monodensified fillers, in contrast to biphasic gels, do not undergo "sizing", a process that breaks down the gel. ${ }^{14}$ As a result, they contain a single phase of HA with a single density. ${ }^{11}$ Different families of monophasic monodensified fillers exist depending on the manufacturing technology, such as the Hylacross ${ }^{\circledR}$ technology (eg, Juvéderm ${ }^{\circledR}$ Ultra, Allergan, Santa Barbara, CA, USA; HA concentration $24 \mathrm{mg} / \mathrm{m})^{14}$ or the Vycross $^{\circledR}$ technology (eg, Juvéderm ${ }^{\circledR}$ Volbella, HA concentration $15 \mathrm{mg} / \mathrm{mL}) .{ }^{15}$ Cohesive monophasic polydensified gels (Belotero ${ }^{\circledR}$ range; Anteis S.A., Geneva, Switzerland, a wholly owned subsidiary of Merz Pharmaceuticals GmbH, Frankfurt am Main, Germany) were more recently introduced. In contrast to monodensified fillers which are crosslinked once, polydensified fillers contain a single phase of HA that is crosslinked continuously. ${ }^{11}$ They are manufactured with the cohesive polydensified matrix $\left(\mathrm{CPM}^{\circledR}\right)$ technology, resulting in a gel with nonuniform crosslinking and molecular weight ${ }^{16}$ and a viscosity that is lower than that of other fillers (comparing fillers targeting the same indication). ${ }^{17}$ These properties allow for a more homogeneous intradermal distribution of the material. ${ }^{3,18}$

The Belotero $^{\circledR}$ range of products offers different densities of HA (concentration ranging from 18 to $26 \mathrm{mg} / \mathrm{mL}$ ) to suit different purposes regarding soft-tissue augmentation and rejuvenation. The first Belotero ${ }^{\circledR}$ dermal filler available on the market was Belotero ${ }^{\circledR}$ Basic, initially launched in Germany in 2005. The equivalent product Belotero ${ }^{\circledR}$ Balance was approved by the US Food and Drug Administration in 2011. The Belotero ${ }^{\circledR}$ range also includes Belotero ${ }^{\circledR}$ Hydro, Soft, Intense, and Volume.

Since their introduction, a large quantity of clinical data has been collected on the Belotero ${ }^{\circledR}$ dermal fillers. The objective of this paper was to review the clinical evidence regarding the performance, tolerability, and safety of the Belotero $^{\circledR}$ dermal fillers for soft-tissue augmentation and rejuvenation.

\section{Materials and methods}

Clinical evidence was reviewed for the whole range of Belotero ${ }^{\circledR}$ dermal fillers, which are briefly described in Table 1.

The PubMed database was searched for all relevant articles up until May 31, 2015, using the following keywords: "Belotero", "Esthélis/Esthelis" (both terms, if number of hits were different), "Fortélis/Fortelis", "Modélis/ Modelis", "Mesolis", "Merz", "Anteis", "hyaluronic", "hyaluronate", "cohesive polydensified matrix", "СРМ technology", "polydense cohesive matrix", and "monophasic polydensified".

The literature search was performed by independent medical writers. Additional references were also retrieved after reading the initial references and review articles. Selected papers were published in peer-reviewed journals in one of the following languages: English, French, and German. Conference abstracts were not considered for review.

The study design, injection procedures and injected volume, population, and main assessments are described for each clinical study in Table 2. Performance assessment was based on quantitative scales, such as the Merz Aesthetics Scales or the Wrinkle Severity Rating Scale (WSRS), or more subjective scales (patient-reported assessment), which are briefly described in Table 3. Less frequently, performance was assessed using objective imaging techniques. Mean wrinkle depth was measured using a 3 dimensional technique called phase-shift rapid in vivo measurement of skin, ${ }^{9,19}$ referred to as skin topography or high-resolution profilometry. ${ }^{20}$ Magnetic resonance imaging (MRI) was used in patients with facial lipoatrophy to quantify the volume of HA, bound water content, skin thickness, and tissue vascularization. ${ }^{21}$ The integration of the filler in the tissue was assessed by ultrasonography, ${ }^{22-24}$ a technique also used to measure skin thickness. 23,24 
Table I Key characteristics and indications of Belotero ${ }^{\circledR}$ dermal fillers and hyaluronic acid fillers used as comparators in split-face, randomized controlled trials

\begin{tabular}{|c|c|c|c|}
\hline Brand name & $\begin{array}{l}\text { Type of filler, crosslinking technology, } \\
\text { and HA concentration (C) }\end{array}$ & Indications and depth of injection & $\begin{array}{l}\text { Countries with marketing } \\
\text { authorization }^{\mathrm{a}}\end{array}$ \\
\hline \multicolumn{4}{|c|}{$\begin{array}{l}\text { Belotero }{ }^{\circledR} \text { dermal fillers (Anteis S.A., Geneva, Switzerland, a wholly owned subsidiary of Merz Pharmaceuticals GmbH, } \\
\text { Frankfurt am Main, Germany) }\end{array}$} \\
\hline Belotero ${ }^{\circledR}$ Hydro & $\begin{array}{l}\text { Non-crosslinked product; also contains } \\
\text { glycerol; } \mathrm{C}=18 \mathrm{mg} / \mathrm{mL}\end{array}$ & $\begin{array}{l}\text { Improvement of skin hydration, radiance, } \\
\text { and elasticity; to be injected into the }\end{array}$ & $\begin{array}{l}\text { EU } \\
\text { Canada }\end{array}$ \\
\hline $\begin{array}{l}\text { Also: Mesolis }{ }^{\circledR} \text { Plus } \\
(\text { or }+)\end{array}$ & & superficial dermis & $\begin{array}{l}\text { Mexico } \\
\text { South Africa } \\
\text { Saudi Arabia }\end{array}$ \\
\hline Belotero ${ }^{\circledR}$ Soft & $\begin{array}{l}\text { Crosslinked product; cohesive } \\
\text { (monophasic) polydensified filler, CPM }{ }^{\circledR}\end{array}$ & $\begin{array}{l}\text { Correction of fine lines (eg, crow's } \\
\text { feet, perioral lines, fine forehead lines); }\end{array}$ & $\begin{array}{l}\text { EU } \\
\text { Canada }\end{array}$ \\
\hline Also: Esthélis ${ }^{\circledR}$ Soft & technology; $\mathrm{C}=20 \mathrm{mg} / \mathrm{mL}$ & $\begin{array}{l}\text { also suitable for lip enhancement and } \\
\text { correction of facial atrophic scars; to } \\
\text { be injected into the superficial-to-mid } \\
\text { dermis }\end{array}$ & $\begin{array}{l}\text { Mexico } \\
\text { Philippines } \\
\text { Russia } \\
\text { South Africa } \\
\text { Saudi Arabia } \\
\text { Korea } \\
\text { Indonesia }\end{array}$ \\
\hline Belotero ${ }^{\circledR}$ Basic/Balance & $\begin{array}{l}\text { Crosslinked product; cohesive } \\
\text { (monophasic) polydensified filler, CPM }\end{array}$ & $\begin{array}{l}\text { Correction of moderate lines } \\
\text { (eg, moderate nasolabial wrinkles, }\end{array}$ & $\begin{array}{l}\text { EU } \\
\text { Canada }\end{array}$ \\
\hline Also: Esthélis ${ }^{\circledR}$ & technology; $\mathrm{C}=22.5 \mathrm{mg} / \mathrm{mL}$ & glabellar lines, moderate perioral & Mexico \\
\hline Basic/Balance & & $\begin{array}{l}\text { wrinkles, lip contouring, philtrum); } \\
\text { also suitable for lip enhancement and } \\
\text { correction of facial atrophic scars; to } \\
\text { be injected into the superficial-to-mid } \\
\text { dermis }\end{array}$ & $\begin{array}{l}\text { Russia } \\
\text { South Africa } \\
\text { Saudi Arabia } \\
\text { USA } \\
\text { Korea } \\
\text { Indonesia }\end{array}$ \\
\hline & $\begin{array}{l}\text { Crosslinked product; cohesive } \\
\text { (monophasic) polydensified filler, CPM }{ }^{\circledR}\end{array}$ & $\begin{array}{l}\text { Correction of deeper lines (eg, severe } \\
\text { NLF, lip volume, oral commissures, }\end{array}$ & $\begin{array}{l}\text { EU } \\
\text { Canada }\end{array}$ \\
\hline Also: Fortélis ${ }^{\circledR}$ Extra & technology; $\mathrm{C}=25.5 \mathrm{mg} / \mathrm{mL}$ & $\begin{array}{l}\text { marionette folds); also suitable for } \\
\text { correction of facial atrophic scars; to be } \\
\text { injected into the deep dermis }\end{array}$ & $\begin{array}{l}\text { Mexico } \\
\text { Russia } \\
\text { South Africa } \\
\text { Saudi Arabia } \\
\text { Korea } \\
\text { Indonesia }\end{array}$ \\
\hline Belotero ${ }^{\circledR}$ Volume & $\begin{array}{l}\text { Crosslinked product; cohesive } \\
\text { (monophasic) polydensified filler, CPM }\end{array}$ & $\begin{array}{l}\text { Restoration of facial volumes } \\
\text { (eg, cheeks, temples, facial volume }\end{array}$ & $\begin{array}{l}\text { EU } \\
\text { Canada }\end{array}$ \\
\hline Also: Modélis ${ }^{\circledast}$ Shape & technology; $\mathrm{C}=26 \mathrm{mg} / \mathrm{mL}$ & $\begin{array}{l}\text { loss); to be injected into the deep } \\
\text { dermis, subcutaneously or on the upper } \\
\text { periostea }\end{array}$ & $\begin{array}{l}\text { South Africa } \\
\text { Saudi Arabia } \\
\text { Korea }\end{array}$ \\
\hline \multicolumn{4}{|c|}{ Hyaluronic acid fillers used as comparators in split-face randomized controlled trials } \\
\hline Restylane $^{\circledR}$ & $\begin{array}{l}\text { Non-cohesive (biphasic) filler, NASHA }{ }^{\circledR} \\
\text { technology; } C=20 \mathrm{mg} / \mathrm{mL}\end{array}$ & $\begin{array}{l}\text { Correction of moderate or severe } \\
\text { wrinkles and folds, lip enhancement; to } \\
\text { be injected into the mid-to-deep dermis }\end{array}$ & $\begin{array}{l}\text { EU } \\
\text { USA } \\
\text { Asia Pacific }\end{array}$ \\
\hline Juvéderm ${ }^{\circledast}$ Ultra 3 & $\begin{array}{l}\text { Cohesive (monophasic) monodensified } \\
\text { filler, Hylacross }{ }^{\circledR} \text { technology; C }=24 \mathrm{mg} / \mathrm{mL}\end{array}$ & $\begin{array}{l}\text { Correction of moderate or severe } \\
\text { wrinkles and folds, lip enhancement; to } \\
\text { be injected into the mid-to-deep dermis }\end{array}$ & $\begin{array}{l}\text { EU } \\
\text { USA } \\
\text { Asia Pacific }\end{array}$ \\
\hline
\end{tabular}

Note: a The listed countries are the ones where the brand Belotero ${ }^{\circledR}$ is on the market, excluding the ones with the sister brands marketed by Anteis.

Abbreviations: $\mathrm{CPM}^{\circledR}$, cohesive polydensified matrix; EU, European Union; HA, hyaluronic acid; NASHA ${ }^{\circledR}$, nonanimal-stabilized hyaluronic acid; NLF, nasolabial fold.

\section{Results}

A total of 26 papers presenting original efficacy or safety clinical data on Belotero ${ }^{\circledR}$ dermal fillers were reviewed (Table 2). Performance and safety findings with Belotero ${ }^{\circledR}$ products are summarized in Table 4.
Of the 26 papers, 20 presented data on Belotero ${ }^{\circledR}$ Basic/ Balance, one on Belotero ${ }^{\circledR}$ Hydro, four on Belotero ${ }^{\circledR}$ Soft, five on Belotero ${ }^{\circledR}$ Intense, and three on Belotero ${ }^{\circledR}$ Volume.

Five papers presented clinical data on more than one Belotero $^{\circledR}$ dermal filler, with or without pooled results 
Table 2 Belotero ${ }^{\circledR}$ dermal fillers: summary of the study design, methods, and main end points

\begin{tabular}{lllll}
\hline $\begin{array}{l}\text { Study, design, and } \\
\text { indication }\end{array}$ & $\begin{array}{l}\text { Treatments and } \\
\text { population }\end{array}$ & Injection technique & Mean injected & Time points and \\
volume & assessments
\end{tabular}

\section{Belotero $^{\circledast}$ Basic/Balance}

RCT (and extension) with comparator(s)

Prager and Steinkraus ${ }^{9, a}$ Belotero ${ }^{\circledast}$ Basic $(n=20)$ vs Restylane ${ }^{\circledast}(n=20)$

RCT split-face NLF

\section{0 patients ( 19 females)}

Mean age: 45.8 years (range $30-60$ years)
Single injection in the mid-to-

deep dermis, using the standard

threading and/or multiple

puncture techniques
I.4 mL for each product
Baseline, 4 weeks

NLF severity: skin topography by PRIMOS

Pain immediately after injection (VAS)

Tolerability, patient's satisfaction, AEs
Prager et $\mathrm{al}^{37, \mathrm{a}}$ RCT split-face NLF

Narins et al ${ }^{36, b}$ RCT split-face NLF

Narins et $\mathrm{al}^{35, \mathrm{~b}}$ RCT split-face Open-label extension NLF Belotero ${ }^{\circledast}$ Basic/Balance $(n=20)$ vs Restylane ${ }^{\circledast}(n=20)\left(\right.$ Arm A); Belotero ${ }^{\circledast}$ Basic/Balance $(n=20)$ vs Juvéderm ${ }^{\circledast}$ Ultra 3 $(n=20)($ Arm B)

Arm A and Arm B: 20 patients (19 females) each Mean age: 45.8 years (range 30-60 years) in Arm A; 45.9 years (range $35-64$ years) in Arm B Belotero ${ }^{\circledR}$ Basic/Balance vs collagen I I 8 patients ( $92.4 \%$ females), Injection using cross-hatching with 106 patients completing or tunneling technique (site not Mean age: 52.4 years (range 25.7-75.7 years)
Single injection in the mid-to-deep Arm A: $1.41 \mathrm{~mL}$ for dermis, with a $27 \mathrm{G}$ needle, using the threading or multiple puncture technique specified), optional touch-up session after 2 weeks
Belotero ${ }^{\circledR}, 1.37 \mathrm{~mL}$ for Restylane ${ }^{\circledR}$; Arm B: $1.42 \mathrm{~mL}$ for Belotero $^{\circledR}, 1.43 \mathrm{~mL}$ for Juvéderm ${ }^{\circledast}$

I.16 mL Belotero ${ }^{\circledR}$ vs Baseline, 2, 4, 8, 12, 16, and $1.37 \mathrm{~mL}$ collagen 24 weeks Touch-up: $0.81 \mathrm{~mL}$ vs $0.94 \mathrm{~mL}$ and 12 months NLF severity (MAS)

Patient's satisfaction, AEs

NLF severity: WSRS (by blinded rater and investigator),

Belotero ${ }^{\circledR}$ Basic/Balance (vs collagen during RCT)

85 completed the extension Touch-up injection possible at 32, At 24 weeks: study $(89.5 \%)$

95 patients ( $92.6 \%$ females) Mean age: 53 years (range 25.7-75.7 years) 48,72 , and 96 weeks Injection 24 weeks after primary $\mathrm{RCT}^{36}$

Multiple injections into mid-to-deep dermis with 27 or $30 \mathrm{G}$ needle
$0.71 \mathrm{~mL}$ for Belotero ${ }^{\circledR}, 1.04 \mathrm{~mL}$ for collagen (further injections at subsequent visits)

Baseline, 4 weeks, then 6, 9, GAIS (by blinded rater, investigator, and patient), VAS fill state (by blinded rater, investigator, and patient) patient's satisfaction and preference, investigator's preference, AEs

NLF severity: WSRS (by investigator), GAIS (by investigator and patient), treatment longevity 24 weeks (=baseline), then 32 , 48, 72, and 96 weeks (after primary RCT)

Antibodies to HA, AEs

Study design other than RCT

\begin{tabular}{|c|c|}
\hline Gregory ${ }^{39}$ & Belotero ${ }^{\circledR}$ Basic/Balance \\
\hline Observational study & 448 patients, representing a \\
\hline Facial treatments & total of 563 facial treatment \\
\hline $\begin{array}{l}\text { (mostly NLF [45\%] and } \\
\text { lip [28\%]) }\end{array}$ & Age range: $32-58$ years \\
\hline Dirting et $\mathrm{a}^{33}$ & Belotero ${ }^{\circledR}$ Basic \\
\hline \multirow[t]{3}{*}{ Prospective study } & I 4 patients ( $90 \%$ females) \\
\hline & mean \pm SD age: \\
\hline & $50.2 \pm 7.1$ years \\
\hline
\end{tabular}

Injection with $30 \mathrm{G}$ needle, mostly into the superficial dermis using a serial puncture technique

Not reported

Follow-up (timing not

Injection in the mid dermis without overcorrection, using linear technique, stratum technique, or a combination of both

No touch-up allowed specified) Patient's satisfaction, AEs

specified)
Patient's satisfaction, AEs

$\mathrm{I} \mathrm{mL}$ on each side Baseline, post-injection, then at 2, 4, 12, and 24 weeks, follow-up at 36 weeks optional WSRS (by blinded rater), GAIS (by investigators and by patients)

Tolerability, AEs 


\begin{tabular}{|c|c|c|c|c|}
\hline $\begin{array}{l}\text { Study, design, and } \\
\text { indication }\end{array}$ & $\begin{array}{l}\text { Treatments and } \\
\text { population }\end{array}$ & Injection technique & $\begin{array}{l}\text { Mean injected } \\
\text { volume }\end{array}$ & $\begin{array}{l}\text { Time points and } \\
\text { assessments }\end{array}$ \\
\hline $\begin{array}{l}\text { Kühne et al }{ }^{38} \\
\text { Retrospective study } \\
\text { Facial treatments } \\
\text { (mostly NLF [25\%] and } \\
\text { marionette lines [18\%]) }\end{array}$ & $\begin{array}{l}\text { Belotero }{ }^{\circledR} \text { Basic / Balance } \\
317 \text { patients ( } 312 \text { females, } \\
98.4 \% ; 309 \text { Caucasians, } \\
97.5 \%) \text { and } 668 \text { treatments } \\
\text { Mean age: } 55 \text { years (range } \\
24-87 \text { years) }\end{array}$ & $\begin{array}{l}\text { Injection intradermally or } \\
\text { superficially subdermally, with } \\
\text { sharp needles ( } 27,28 \text {, or } 30 \mathrm{G} \\
\text { depending on the depth of } \\
\text { injection and area to be treated), } \\
\text { using microdroplet, linear } \\
\text { threading, fanning, cross-hatching, } \\
\text { or bolus }\end{array}$ & $\begin{array}{l}0.2-3.0 \mathrm{~mL} \text {, } \\
\text { depending on the } \\
\text { area treated }\end{array}$ & $\begin{array}{l}\text { 5-Year review } \\
\text { Performance not formally } \\
\text { assessed } \\
\text { AEs }\end{array}$ \\
\hline Downie et $\mathrm{al}^{34}$ & Belotero ${ }^{\circledR}$ Basic/Balance & & & \\
\hline $\begin{array}{l}\text { Open-label study } \\
\text { NLF }\end{array}$ & $\begin{array}{l}93 \text { patients ( } 80 \text { females) } \\
\text { Mean age: } 57.3,50.9 \text {, and } \\
5 I .5 \text { years in skin types } \\
\text { IV }(n=4), V(n=37) \text {, and VI } \\
(n=52) \text {, respectively }\end{array}$ & $\begin{array}{l}\text { Multiple injection in the } \\
\text { mid-to-deep dermis with a } 27 \\
\text { or } 30 \mathrm{G} \text { needle, optional touch-up } \\
\text { session after } 2 \text { weeks }\end{array}$ & $\begin{array}{l}\text { Up to } 3 \mathrm{~mL} \text { per NLF } \\
\text { over two sessions }\end{array}$ & $\begin{array}{l}\text { Baseline, } 2,4,8,12,16 \text {, and } \\
24 \text { weeks } \\
\text { NLF severity: WSRS (by } \\
\text { investigator and independent } \\
\text { rater), GAIS (by patient) } \\
\text { AEs }\end{array}$ \\
\hline $\begin{array}{l}\text { Gilbert and Calvisi }{ }^{42} \\
\text { Case series }\end{array}$ & \multicolumn{4}{|c|}{$\begin{array}{l}\text { Belotero }{ }^{\circledR} \text { Balance }(n=I) \text {, Restylane }{ }^{\circledR}+\text { lidocaine }(n=I) \text {, Perlane }{ }^{\circledR}+ \\
\text { lidocaine }(n=3) \text {, Radiesse }{ }^{\circledR}(n=I)\end{array}$} \\
\hline $\begin{array}{l}\text { Facial treatments } \\
\text { (mostly mid-face }[7 \mid \%] \text { ) }\end{array}$ & $\begin{array}{l}\text { Seven patients (seven } \\
\text { females) } \\
\text { Age range: } 40-88 \text { years }\end{array}$ & $\begin{array}{l}\text { Belotero }{ }^{\circledR} \text { Basic/Balance injected } \\
\text { into the lips with a } 32 \mathrm{G} \text { needle }\end{array}$ & $\mathrm{I} \mathrm{mL}$ & $\begin{array}{l}\text { Discussion regarding the } \\
\text { choice of each filler (no formal } \\
\text { efficacy assessments) }\end{array}$ \\
\hline Goh et $\mathrm{al}^{22}$ & \multicolumn{4}{|c|}{ Belotero ${ }^{\circledR}$ Balance $(n=5)$ and Restylane ${ }^{\circledR}-L(n=5)$} \\
\hline $\begin{array}{l}\text { Retrospective chart } \\
\text { review }\end{array}$ & $\begin{array}{l}\text { Ten patients (eight females) } \\
\text { Median age: } 57 \text { years (range }\end{array}$ & $\begin{array}{l}\text { Injection along or } 2-6 \mathrm{~mm} \text { below } \\
\text { the infraorbital rim, with } 30 \mathrm{G}\end{array}$ & $\begin{array}{l}\text { I } \mathrm{mL} \text { of filler }(0.5 \text { on } \\
\text { each side) }\end{array}$ & $\begin{array}{l}\text { Before and immediately after } \\
\text { injection }\end{array}$ \\
\hline Infraorbital hollow & $\begin{array}{l}37-84 \text { years) for Belotero }{ }^{\circledR} \text {, } \\
6 \text { I years (range } 47-80 \text { years) } \\
\text { for Restylane }{ }^{\circledR}-L\end{array}$ & $\begin{array}{l}\text { needle using a combination } \\
\text { of direct serial puncture and } \\
\text { retrograde linear threading } \\
\text { technique }\end{array}$ & & $\begin{array}{l}\text { Distribution pattern of filler } \\
\text { by high-resolution ultrasound } \\
\text { AEs }\end{array}$ \\
\hline Hevia et $\mathrm{al}^{40}$ & Belotero ${ }^{\circledR}$ Balance & & & \\
\hline $\begin{array}{l}\text { Prospective study } \\
\text { Infraorbital hollow }\end{array}$ & $\begin{array}{l}49 \text { patients, with } 46 \text { patients } \\
\text { (38 females) completers } \\
\text { Mean age: } 51 \text { years (range } \\
31-67 \text { years) }\end{array}$ & $\begin{array}{l}\text { Repeated injections with a } 30 \mathrm{G} \\
\text { needle, using retrograde injection } \\
\text { Generally three to five entry sites } \\
\text { medially, two to three centrally, } \\
\text { three to five laterally; repeated } \\
\text { as often as needed to correct the } \\
\text { deficient volume }\end{array}$ & $\begin{array}{l}0.92 \mathrm{~mL} \text { on each side } \\
\text { at baseline, } 0.27 \mathrm{~mL} \\
\text { at touch-up, and } \\
0.21 \mathrm{~mL} \text { at } 6 \text { months } \\
\text { (re-treatment) }\end{array}$ & $\begin{array}{l}\text { Baseline, 2, 8, 24, and } \\
40 \text { weeks } \\
\text { Hollowness (Merz Aesthetics } \\
\text { Infraorbital Hollow Scale }{ }^{\mathrm{TM}} \text { ) } \\
\text { AEs }\end{array}$ \\
\hline Wollina $^{41}$ & \multicolumn{4}{|c|}{ Belotero ${ }^{\circledR}$ Basic $(n=2 I)$, Glytone ${ }^{\circledR} 3(n=10)$, and Radiesse ${ }^{\circledR}$ (calcium hydroxyapatite, $\left.n=9\right)$} \\
\hline Retrospective study & 40 patients (all females) & Single injection with a $30 \mathrm{G}$ & $0.2-0.6 \mathrm{~mL}$ for $\mathrm{HA}$ & Baseline, 2 or 3 weeks \\
\hline Tear trough & $\begin{array}{l}\text { mean } \pm \text { SD age: } \\
50 \pm I I . I \text { years (range: } 32-90 \\
\text { years) }\end{array}$ & $\begin{array}{l}\text { needle, using linear threading } \\
\text { technique } \\
\text { Touch-up if necessary at } 2 \text { or } \\
3 \text { weeks }\end{array}$ & $\begin{array}{l}\text { fillers (different } \\
\text { volume for } \\
\text { Radiesse }^{\circledR} \text { ) }\end{array}$ & $\begin{array}{l}\text { Fold severity (Hirmand's } \\
\text { classification) } \\
\text { AEs }\end{array}$ \\
\hline
\end{tabular}

Effect of lidocaine Moradi et $\mathrm{al}^{31}$ RCT split-face Perioral lines

Prager and Micheels ${ }^{32}$ Prospective survey, split-face Facial treatments (mostly NLF [79\%], marionette lines [62\%])

Belotero ${ }^{\circledR}$ Balance (BEL, $\left.n=10\right)$, Belotero ${ }^{\circledR}$ Balance with lidocaine (BEL + lido, $\left.n=10\right)$, Belotero ${ }^{\circledR}$ Balance with lidocaine + epinephrine (BEL + lido + epi, $n=10)$

30 females Injection with a $30 \mathrm{G}$ needle, into $\mathrm{I} \mathrm{mL}$ per side

Age range: $18-75$ years the superficial dermis using serial punctures and linear threading techniques

Belotero ${ }^{\circledR}$ Basic/Balance with/without lidocaine

29 females Technique depended on the

Mean age: 53.5 years (range: site but was identical on both 30.6-82.9 years) half-face, use of needle or cannula, either manually or with the aid of an injection system, most often in the superficial dermis $(62.1 \%)$
Baseline, days I, 7, and I4 Patient-assessed pain, AEs

I $\mathrm{mL}$ maximum on No specific time points each side of the face, (survey) per zone

Physician's experience (ease of use, distribution of product in the skin, satisfaction, etc) Patient's pain and satisfaction, AEs

(Continued) 
Table 2 (Continued)

\begin{tabular}{llll}
\hline $\begin{array}{l}\text { Study, design, and } \\
\text { indication }\end{array}$ & $\begin{array}{l}\text { Treatments and } \\
\text { population }\end{array}$ & Injection technique & Mean injected \\
\hline
\end{tabular}

\section{Belotero $^{\circledast}$ Hydro \\ Study design other than RCT \\ Succi et $\mathrm{al}^{44} \quad$ Mesolis ${ }^{\circledR}$ Plus \\ Open-label study 20 patients (all females) \\ Periorbital area Mean age: 50 years (range \\ 29-59 years) \\ Injection in the superficial dermis with $30 \mathrm{G}$ needle, using the micropuncture technique Three monthly sessions}

\section{Belotero ${ }^{\circledR}$ Soft (and/or other Belotero ${ }^{\circledR}$ dermal fillers) \\ Bezzola and Micheels ${ }^{27, c}$ Esthélis ${ }^{\circledR}$ Basic and Soft Open-label study 36 patients \\ Facial treatments Soft, $\mathrm{n}=\mathrm{II}$ (ten females) Basic, $\mathrm{n}=25$ (20 females) Age not provided}

Micheels ${ }^{26, c}$

Esthélis ${ }^{\circledR}$ Basic and Soft

Safety follow-up report 13 patients (ten females) out Facial treatments of the 36 included in the pilot study

Mean age: 55 years (range 40-7l years)

Hasson and Romero ${ }^{25}$ Facial atrophic scars 12 patients
Age: $18-56$ Age: 18-56 years Prospective study

Injection with 27 or $30 \mathrm{G}$

needle into the superficial dermis, blanket method with the whitening technique, or into the middle or deep dermis, using point-by-point injection (Soft) or retro-tracing or prograde technique (Basic)

Single injection with $30 \mathrm{G}$ needle (for the patients who did the follow-up) Regular treatments until month 24 (5.7 injections per patients on average)

Injection with $30 \mathrm{G}$ needle into the superficial or mid dermis, using linear threading, serial puncture, or a combination of both

Pavicic et a ${ }^{30}$ Case series Whole-face rejuvenation

Belotero $^{\circledR}$ Intense RCT with comparator(s) Buntrock et al ${ }^{19}$ RCT split-face NLF
Belotero $^{\circledR}$ Intense vs Perlane ${ }^{\circledR}$

20 patients ( 18 females)

Mean age: $52.0 \pm 5.6$ years
Single injection in deep dermis, using $27 \mathrm{G}$ needle and standard serial puncture technique

$0.74 \mathrm{~mL}$ per session

Baseline, 2 weeks after sessions 2 and 3 Physician Clinical Global Assessment (by the three investigators and a blinded rater)

Patient's satisfaction, AEs

Soft: $0.1-0.6 \mathrm{~mL}$ per treatment session, one or two treatment sessions Basic: 0.3-1.5 mL, one or two treatment sessions

Not reported$$
\text { . }
$$

(1)




\begin{tabular}{lllll}
\hline $\begin{array}{l}\text { Study, design, and } \\
\text { indication }\end{array}$ & $\begin{array}{l}\text { Treatments and } \\
\text { population }\end{array}$ & Injection technique & $\begin{array}{l}\text { Mean injected } \\
\text { volume }\end{array}$ & $\begin{array}{l}\text { Time points and } \\
\text { assessments }\end{array}$ \\
\hline
\end{tabular}

Study design other than RCT

Pavicic et $\mathrm{a}^{29} \quad$ Belotero ${ }^{\circledR}$ Basic and Belotero ${ }^{\circledR}$ Intense combined

Case series Two HIV-infected patients Case I: three syringes Basic

HIV-associated facial Case I: 38-year-old man

lipoatrophy Case 2: 56-year-old man

Micheels ${ }^{45}$
Observational study
(+ histology)
Facial treatments

Pavicic $^{28}$

Open-label study

Facial treatments

(mostly NLF [84\%])

\section{Fortélis ${ }^{\circledast}$ Extra}

28 patients (20 females)

Mean age: 53 years (range

33-67 years)

One patient for histology

(skin of the thigh) at baseline, then two and one

syringes Basic at 6 and 12 months, respectively, then two syringes

Intense at 18 months; no further treatment at 30 months

Case 2: two syringes Basic at baseline, then two syringes Basic at 8 months, then two syringes Intense at 20 months

\section{Injection in the mid-to-deep}

dermis, with a Kendall-type $27 \mathrm{G}$

needle, using preferably the

retrograde tunneling (or slow

local infiltration to create volume)
Up to $2 \mathrm{~mL}$ at each Case I: baseline, then 6, 12, treatment session, in 18 , and 30 months

both cases

Case 2: baseline, then 8, 20, and 26 months

Severity of the facial lipoatrophy (facial lipoatrophy severity scale)

AEs

Reported for some patients but not the whole sample

Belotero $^{\circledR}$ Intense alone $(\mathrm{n}=\mathrm{I}$ 149 patients ( $88.9 \%$ females) Mean age: 52.2 years (range 25-77 years)

\section{Belotero ${ }^{\circledR}$ Volume}

Study design other than RCTs

Micheels et al ${ }^{47} \quad$ Belotero $^{\circledR}$ Volume

Observational study 56 patients

Facial volume loss Mean age: $59.8 \pm 13.6$ years

(mostly cheeks [38.6\%], (range: $25-76$ years)

cheekbones [18.1\%],

tear trough [18.1\%])

\section{Becker et $\mathrm{al}^{21}$ Observational study HIV-associated facial lipoatrophy}

Modélis ${ }^{\circledR}$ Shape

Ten male patients

Mean age: $56.4 \pm 6.4$ years

\author{
Majority of injections performed \\ at a deep dermal/hypodermal \\ depth or to the level of the \\ supraperiosteal plane, using \\ needle or cannula (most common \\ size: $27 \mathrm{G}, 46.3 \%$ of cases; $25 \mathrm{G}$, \\ $25.9 \%$ of cases) \\ Optional touch-up at I month \\ $(n=2)$ \\ $0.58 \mathrm{~mL}$ per side
}

Subdermal injection in submalar area with $25 \mathrm{G}$ short needle completed with $22 \mathrm{G}$ microcannula of $50 \mathrm{~mm}$ length, using a retrograde and fanning technique, optional touch-up session after 2 weeks Two or three punctures per session Modélis $^{\circledR}$ Shape/Belotero ${ }^{\circledR}$ Volume

Micheels et al ${ }^{46}$ Post-marketing clinical follow-up Age-related mid face atrophy

\section{0 patients}

Mean age: 57 years (range

28-73 years)
Injection in lateral cheek hollow $(n=8)$, cheekbone area $(n=6)$, or both $(n=6)$, with needles and cannulae, using different methods depending on the investigator. Optional touch-up injection
I.3 mL per cheek

2.I $\mathrm{mL}$ for both sides for injection in lateral cheek hollow, $2.1 \mathrm{~mL}$ for injection in cheekbone area, $3.37 \mathrm{~mL}$ for injection in both
Efficacy: baseline, 6 months, $\geq 10$ months

Esthetic improvement discussed but not quantified Histology: day 0 , day 90 AEs

$n=39$ )

Baseline, immediately after injection, and at 2 and 12 weeks Fold severity: WSRS, GAIS Overall esthetic effect (by physician)

Investigator's satisfaction Patient's satisfaction, AEs
Baseline, I, 3, and 6 months Esthetic effect: FVLS by investigator, GAIS by investigator and patient Patient's satisfaction Investigator's experience AEs

Baseline, I, 6, and 12 months $\mathrm{HA}$ volume, skin thickness, and tissue vascularization by MRI Patient's satisfaction GAIS (by investigator and patient)

AEs

Baseline, immediately after injection, and I, 3, 6, 9, 12 (and optionally 18) months Esthetic effect: FVLS by investigator, GAIS by investigator and patient Patient's satisfaction AEs

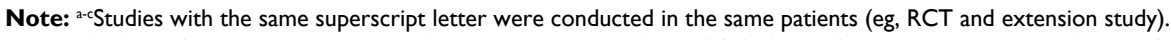

Abbreviations: AEs, adverse events; FVLS, Facial Volume Loss Scale; GAIS, Global Aesthetic Improvement Scale; HA, hyaluronic acid; MAS, Merz Aesthetics Scales; MRI, magnetic resonance imaging; NLF, nasolabial fold; PRIMOS, phase-shift rapid in vivo measurement of skin; RCT, randomized controlled trial; VAS, visual analog scale; WSRS, Wrinkle Severity Rating Scale. 
Table 3 Performance assessment of dermal fillers: rating scales, and investigator's and patient's satisfaction

\begin{tabular}{|c|c|c|c|}
\hline $\begin{array}{l}\text { Assessment } \\
\text { Rating scales }\end{array}$ & Description & End points/definition & Reference \\
\hline WSRS & $\begin{array}{l}\text { Discrete 5-point } \\
\text { scale }\end{array}$ & $\begin{array}{l}\text { Fold severity } \\
\text { From } 0 \text { - absent (no visible fold; continuous skin line), to } 4 \text { - extreme (extremely deep and long } \\
\text { folds detrimental to facial appearance to } 4 \mathrm{~mm} \mathrm{V-shaped} \mathrm{fold} \mathrm{when} \mathrm{stretched)}\end{array}$ & 58 \\
\hline $\begin{array}{l}\text { GAIS (not } \\
\text { validated) }\end{array}$ & $\begin{array}{l}\text { Discrete 5-point } \\
\text { scale }\end{array}$ & $\begin{array}{l}\text { Esthetic outcomes compared to baseline } \\
\text { From I - worse to } 5 \text { - very much improved }\end{array}$ & \\
\hline VAS fill state & $\begin{array}{l}\text { Continuous } \\
\text { scale }(0 \%-100 \%)\end{array}$ & Fold correction (ie, improvement) rated from $0 \%$ to $100 \%$ & \\
\hline $\begin{array}{l}\text { Overall esthetic } \\
\text { effect }\end{array}$ & $\begin{array}{l}\text { Discrete 6-point } \\
\text { scale }\end{array}$ & From I - excellent to 6 - unsatisfactory & \\
\hline FVLS & $\begin{array}{l}\text { Discrete 5-point } \\
\text { scale }\end{array}$ & $\begin{array}{l}\text { From I - mild flattening/no visibility of underlying tissue, to } 5 \text { - severe indentation of one or } \\
\text { more facial regions/clear visibility of underlying tissue }\end{array}$ & 59 \\
\hline $\begin{array}{l}\text { Facial } \\
\text { lipoatrophy } \\
\text { severity scale }\end{array}$ & $\begin{array}{l}\text { Discrete 4-point } \\
\text { scale }\end{array}$ & $\begin{array}{l}\text { From I - mild and localized facial lipoatrophy, to } 4 \text { - lipoatrophy covers a wide area, extending } \\
\text { up toward the eye sockets, and the facial skin lies directly on the muscles }\end{array}$ & \\
\hline MAS & $\begin{array}{l}\text { Discrete 5-point } \\
\text { scales }\end{array}$ & $\begin{array}{l}\text { Scales for the lower face (NLFs, marionette lines, upper and lower lip fullness, lip wrinkles, oral } \\
\text { commissures, and jawline) } \\
\text { Scales for the mid face (infraorbital hollow and upper and lower cheek fullness) } \\
\text { Scales for the upper face (forehead lines, glabellar lines, crow's feet, sex-specific brow } \\
\text { positioning, and summary scores of forehead and crow's feet areas and of the entire upper } \\
\text { face unit) }\end{array}$ & $60-62$ \\
\hline $\begin{array}{l}\text { Hirmand's } \\
\text { classification }\end{array}$ & $\begin{array}{l}\text { Discrete 3-point } \\
\text { scale }\end{array}$ & $\begin{array}{l}\text { Severity of tear trough deformity } \\
\text { From Class I - loss of volume limited medially down to Class III - full depression } \\
\text { circumferentially to the orbital rim }\end{array}$ & 63 \\
\hline $\begin{array}{l}\text { Physician's } \\
\text { clinical global } \\
\text { assessment }\end{array}$ & $\begin{array}{l}\text { Discrete 7-point } \\
\text { scale }\end{array}$ & $\begin{array}{l}\text { Rating of skin's appearance (brightness, texture, and turgor), from 100\% improvement down to } \\
\text { worsening }\end{array}$ & \\
\hline Satisfaction wi & $h$ the product (ar & d related factors) & \\
\hline $\begin{array}{l}\text { Practitioner's } \\
\text { satisfaction }\end{array}$ & $\begin{array}{l}\text { Ease of use, } \\
\text { esthetic } \\
\text { outcomes, etc }\end{array}$ & Overall satisfaction/preference & \\
\hline $\begin{array}{l}\text { Patient's } \\
\text { satisfaction }\end{array}$ & $\begin{array}{l}\text { Various } \\
\text { assessments }\end{array}$ & $\begin{array}{l}\text { Overall satisfaction/preference } \\
\text { Specific questions such as whether the patient felt the implant, whether the patient would } \\
\text { recommend the treatment, whether the patient's expectations were met and he/she would } \\
\text { repeat the treatment course } \\
\text { Quality-of-life questionnaire }\end{array}$ & \\
\hline Pain (VAS) & $\begin{array}{l}\text { Discrete } \\
\text { II-point scale }\end{array}$ & 0 - no pain to 10 -worst imaginable pain & \\
\hline $\begin{array}{l}\text { Treatment } \\
\text { longevity }\end{array}$ & $\begin{array}{l}\text { Various } \\
\text { assessments }\end{array}$ & $\begin{array}{l}\text { Percentage of patients not requiring injections; percentage of patients who persist without } \\
\text { repeat treatment for a given length of time; cumulative number of injections received for a } \\
\text { given length of time; average time between injections; time lag between the first and the second } \\
\text { treatment sessions }\end{array}$ & \\
\hline
\end{tabular}

Note: The last column ("Reference") refers to the publication describing/validating the scale, if any.

Abbreviations: FVLS, Facial Volume Loss Scale; GAIS, Global Aesthetic Improvement Scale; MAS, Merz Aesthetics Scales; NLF, nasolabial fold; VAS, visual analog scale; WSRS, Wrinkle Severity Rating Scale.

(Esthélis ${ }^{\circledR}$ Basic and Soft, ${ }^{25-27}$ Belotero ${ }^{\circledR}$ Basic/Balance, and Intense $\left.\mathrm{e}^{28,29}\right)$, and one paper presented data on a combination of products (Belotero ${ }^{\circledR}$ dermal filler injected after botulinum toxin and calcium hydroxyapatite ${ }^{30}$ ).

In all but two studies, ${ }^{31,32}$ the Belotero ${ }^{\circledR}$ dermal fillers did not contain lidocaine, since the addition of lidocaine to the Belotero $^{\circledR}$ range is relatively recent (April 2014 for Belotero ${ }^{\circledR}$ Basic/Balance and Belotero ${ }^{\circledR}$ Intense, January 2015 for Belotero ${ }^{\circledR}$ Volume).

\section{Belotero ${ }^{\circledR}$ Basic/Balance}

Among the 20 studies that investigated the performance and safety of Belotero ${ }^{\circledR}$ Basic/Balance, six were focused on nasolabial folds (NLFs), ${ }^{9,33-37}$ five on various facial areas, ${ }^{26,27,32,38,39}$ two on infraorbital hollow, ${ }^{22,40}$ one on tear trough, ${ }^{41}$ one on lip volume restoration, ${ }^{42}$ one on perioral lines, ${ }^{31}$ and one on atrophic scars..$^{25}$ In addition, three studies presented data on Belotero ${ }^{\circledR}$ Basic/Balance combined to other Belotero ${ }^{\circledR}$ dermal fillers for deep lines and wrinkles 
filling ${ }^{28}$ whole-face rejuvenation, ${ }^{30}$ or HIV-associated facial lipoatrophy. ${ }^{29}$

The state of the literature is consistent with the indications most frequently treated with Belotero ${ }^{\circledR}$ Basic/Balance. In a 5-year chart review including 317 patients and 668 treatments, the areas most commonly treated were the NLFs (166 treatments, $24.9 \%$ ), the marionette lines (122 treatments, $18.3 \%$ ), and the perioral lines (106 treatments, $15.9 \%){ }^{38}$

\section{Performance of Belotero ${ }^{\circledR}$ Basic/Balance Nasolabial folds}

Two randomized controlled trials (RCTs) using a split-face design have been conducted on Belotero ${ }^{\circledR}$ Basic/Balance, with other HA fillers (Restylane ${ }^{\circledR}$, Juvéderm ${ }^{\circledR}$ Ultra 3, n=20 per arm $)^{9,37}$ and bovine collagen $(\mathrm{n}=118)^{35,36}$ as comparators. In both cases, the treated area was the NLF, which was rated as moderate to severe at baseline.

Short-term performance of the fillers was evaluated immediately after injection and after $2-4$ weeks. To assess treatment longevity, further assessments were regularly performed, with a last evaluation at $6,{ }^{36} 12,{ }^{37}$ and up to 22 months (ie, 96 weeks). ${ }^{35}$
Based on skin topography, the mean reduction in the wrinkle depth at 4 weeks was shown to be greater with Belotero ${ }^{\circledR}$ Basic/Balance $(-109.5 \mu \mathrm{m})$ than with Restylane ${ }^{\circledR}$ $\left(-71.8 \mu \mathrm{m}, P<0.0001\right.$; Figure 1 and Table 4). ${ }^{9}$

Positive findings were also reported using quantitative scales (Figure 2). Greater changes in WSRS scores (assessed by a blinded rater) were obtained with Belotero ${ }^{\circledR}$ Basic/ Balance than with collagen, $8,12,16$, and 24 weeks after injection $(P<0.01) .{ }^{36}$ These results were globally confirmed by the Global Aesthetic Improvement Scale (GAIS) scores and the visual analog scale fill state scores (Table 4).$^{36}$ Lower scores on Merz Aesthetics Scales were obtained at 4 weeks than at baseline with Belotero ${ }^{\circledR}$ Basic/Balance, Restylane ${ }^{\circledR}$, and Juvéderm ${ }^{\circledR}$ Ultra 3, with no statistically significant differences between fillers. ${ }^{37}$

Regarding treatment longevity, the fold severity scores were still lower than at baseline for Belotero ${ }^{\circledR}$ Basic/Balance, Restylane ${ }^{\circledR}$, and Juvéderm ${ }^{\circledR}$ Ultra 3 up to 12 months after injection (1.5 or 1.6 vs 2.3 at baseline, respectively). ${ }^{37} \mathrm{In}$ the open-label 18 -month extension study, with re-treatment at 24 weeks and optional touch-up injections thereafter, treatment effects persisted without re-treatment for at least 48 weeks in $80.2 \%$ of patients, both with Belotero ${ }^{\circledR}$

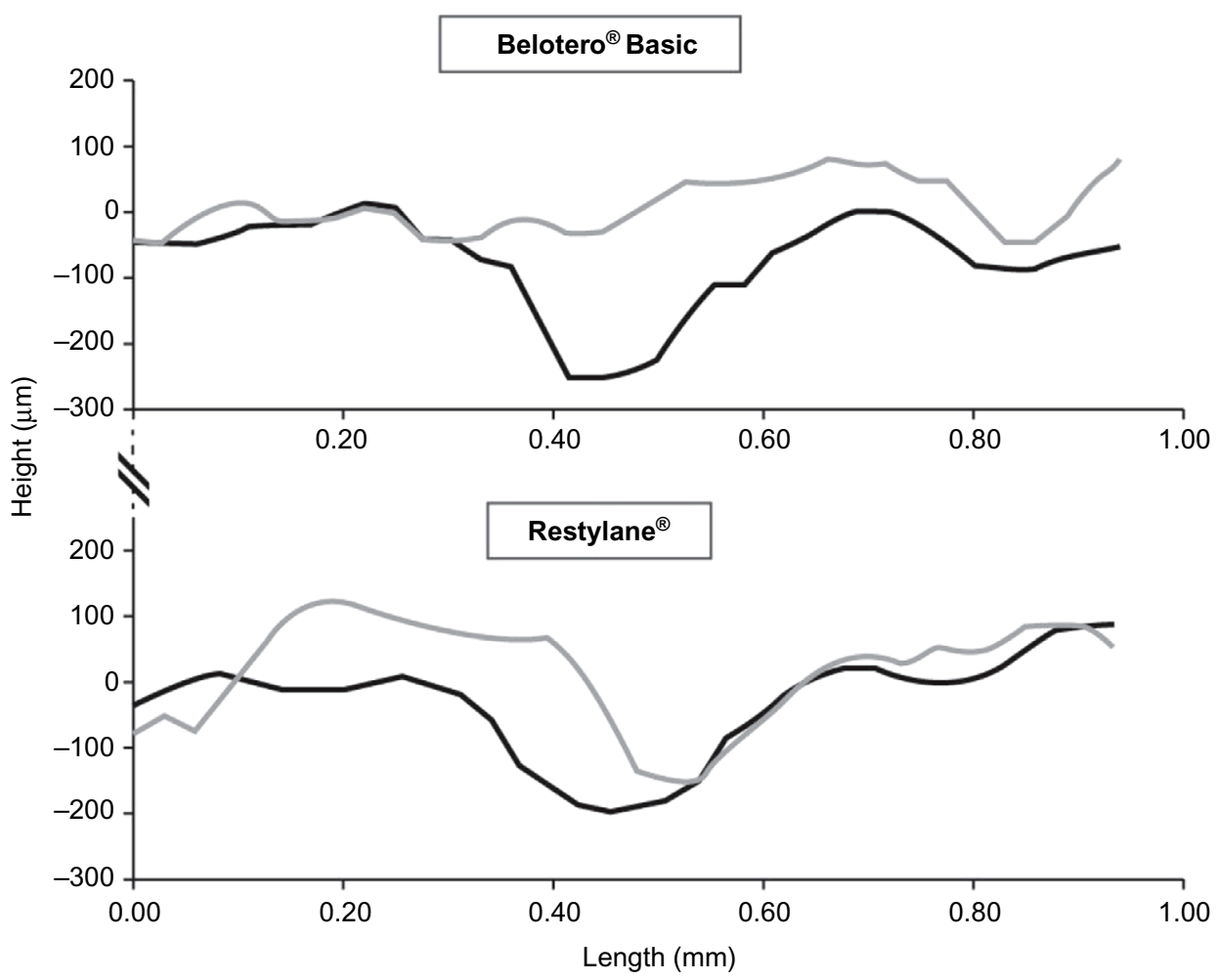

Figure I Two-dimensional surface profiles before (black lines) and 4 weeks after treatment (gray lines) with Belotero ${ }^{\circledR}$ Basic and Restylane ${ }^{\circledR}$.

Notes: Height $(\mu \mathrm{m})$ on the vertical axis corresponds to wrinkle depth. It was calculated as the mean of 50 profile lines across the wrinkles of the target area, using the phaseshift rapid in vivo measurement of skin system. Adapted from Prager W, Steinkraus V. A prospective, rater-blind, randomized comparison of the effectiveness and tolerability of Belotero ${ }^{\circledR}$ Basic versus Restylane ${ }^{\circledR}$ for correction of nasolabial folds. Eur J Dermatol. 2010;20(6):748-752. ${ }^{9}$ 
Table 4 Belotero ${ }^{\circledR}$ dermal fillers: summary of clinical findings

\begin{tabular}{|c|c|c|c|}
\hline $\begin{array}{l}\text { Study, design, and } \\
\text { indication }\end{array}$ & Treatments and performance & Pain, safety, and tolerability & $\begin{array}{l}\text { Investigator's and patient's } \\
\text { satisfaction }\end{array}$ \\
\hline
\end{tabular}

\section{Belotero $^{\circledast}$ Basic/Balance}

RCT (and extension) with comparator(s)

Prager and $\quad$ Belotero ${ }^{\circledR}$ Basic $(n=20)$ vs Restylane ${ }^{\circledR}(n=20)$

Steinkraus 9 a a reduction in wrinkle depth Pain immediately after injection (by VAS):

RCT split-face at 4 weeks: greater with Belotero ${ }^{\circledR}$

NLF $\quad(-109.5 \mu \mathrm{m})$ than with Restylane ${ }^{\circledR}$

$(-7 \mathrm{I} .8 \mu \mathrm{m}, P<0.000 \mathrm{I})$ lower with Belotero ${ }^{\circledR}$ (ns)

Most common AEs: injection-site erythema

(Belotero $^{\circledR} n=7,35 \%$; Restylane ${ }^{\circledR} n=6,30 \%$ ),

hematoma (Belotero ${ }^{\circledR} n=1,5 \%$; Restylane ${ }^{\circledR} n=2$, $10 \%)$

All AEs of mild or moderate severity

No SAEs, no AEs leading to discontinuation

Tolerability rated as good/very good by $85 \%$

of patients with Belotero ${ }^{\circledR}$ vs $80 \%$ of patients

with Restylane ${ }^{\circledR}$ (and in $90 \%$ of cases with both

treatments, by the investigators)
Prager et $\mathrm{al}^{37, \mathrm{a}}$ RCT split-face NLF

Narins et $a^{36, b}$ RCT split-face NLF
Belotero ${ }^{\circledR}$ Basic/Balance $(n=20)$ vs Restylane ${ }^{\circledast}(n=20)\left(\right.$ Arm A); Belotero ${ }^{\circledR}$ Basic/Balance $(n=20)$ vs Juvéderm ${ }^{\circledast}$ Ultra $3(n=20)$ (Arm B)

NLF severity: lowest score obtained at Most common AEs: erythema (Belotero ${ }^{\circledR}$ week 4 , regardless of the filler ( 0.8 or 0.9 , Arm $A+B n=14,35 \%$; Restylane ${ }^{\circledR} n=6,30 \%$; depending on Arm). Scores still lower at Juvéderm ${ }^{\circledR} n=8,40 \%$ ), hematoma (Belotero ${ }^{\circledR}$ 12 months ( 1.5 or 1.6 ) than at baseline $\quad \operatorname{Arm} A+B n=4,10 \%$; Restylane ${ }^{\circledR} n=3,15 \%$; (2.3), for all fillers No statistical difference between fillers Juvéderm ${ }^{\circledR} n=4,20 \%$ ), edema (Belotero ${ }^{\circledR}$ Arm A + B n=I, 2.5\%; Restylane ${ }^{\circledast} n=0,0 \%$; Juvéderm ${ }^{\circledR} n=5,25 \%$ )

Most AEs of mild or moderate severity, except one severe $A E$ (pain in one patient with Belotero $^{\circledast}$ in Arm B). No SAEs, no AEs leading to discontinuation

Belotero ${ }^{\circledR}$ Basic/Balance vs collagen $(n=\mid 18)$ Change in WSRS at 12 weeks (by blinded rater) greater with Belotero ${ }^{\circledR}(P<0.001)$ : from 2.50 to $1.25(-1.25)$ vs 2.49 to I.5I $(-0.98)$ with collagen

Other significant differences in favor of Belotero $^{\circledR}$ : WSRS (blinded rater) at 8,12 , 16, and 24 weeks; WSRS (investigator) at 12, 16, and 24 weeks; GAIS (blinded rater and investigator) at $8,12,16$, and 24 weeks; GAIS (patient) at 8, 16, and 24 weeks; VAS fill state (blinded rater, investigator, and patient) at $8,12,16$, and 24 weeks (except patient VAS at week 8 ) Responder rate (\% of patients showing a difference in WSRS of $\geq 1$ point between Belotero ${ }^{\circledR}$ and collagen): $15.9 \%$ at 2 weeks, $55.1 \%$ at 24 weeks
Injection-site pain: $44.9 \%$ with Belotero ${ }^{\circledR}, 53.4 \%$ with collagen; generally mild to moderate Related AEs in $\geq 2 \%$ of full analysis set: 167 AEs with Belotero ${ }^{\circledR}, 217$ AEs with collagen Injection-site AEs (Belotero ${ }^{\circledR}$ vs collagen): nodule (33.1\% vs $55.1 \%$ ), induration $(33.9 \%$ vs $40.7 \%$ ), swelling ( $22.9 \%$ vs $22.0 \%$ ), pruritus (5.1\% vs $7.6 \%$ ), pain (5.1\% vs $4.2 \%$ ), erythema ( $2.5 \%$ vs $4.2 \%$ ), bruising ( $3.4 \%$ vs $0.8 \%$ ), discoloration ( $0 \%$ vs $4.2 \%$ )

Most injection-site AEs mild or moderate in intensity and resolved within 7 days Severe procedure-related AEs: with Belotero ${ }^{\circledR}$, swelling (6.8\%) and bruising (8.5\%); with collagen (and occurring in $\geq 5 \%$ of patients)

erythema (8.5\%) and swelling (8.5\%)

Severe AEs related to product itself: with Belotero ${ }^{\circledR}$, nodule only $A E$ reported in $\geq 5 \%$ of patients (5.9\%); with collagen, AEs reported in $\geq 5 \%$ of patients were nodule $(7.6 \%)$ and induration (5.9\%)

Bruising, nodules, swelling, and induration were the AEs that lasted longer than a week in $>10 \%$ of patients
Patient's satisfaction: felt the implant: $65 \%$ with Belotero ${ }^{\circledR}$, $75 \%$ with Restylane ${ }^{\circledR}$ $55 \%$ would recommend both products

Of those who would recommend one product: $25 \%$ Belotero $^{\circledast}, 10 \%$ Restylane $^{\circledast}$

Patient's satisfaction: both fillers acceptable: Arm A 55\%, Arm B 25\%

Preferred Belotero ${ }^{\circledR}$ : Arm A $25 \%$, Arm B $40 \%$

Preferred other filler: Arm A Restylane ${ }^{\circledR} 10 \%$, Arm B Juvéderm ${ }^{\circledast} 35 \%$ No preference: Arm A 10\%, Arm B 0\%

Patient's questionnaire $(n=107)$ : 79.4\% preferred Belotero ${ }^{\circledR}$ at 24 weeks. Improvement and satisfaction (VAS) rated at $74.7 \%$ and $78.2 \%$ with Belotero ${ }^{\circledR}$ vs $66.0 \%$ and $65.1 \%$ with collagen Five out of six investigators preferred Belotero ${ }^{\circledR}$ because of its storage and handling, and comfort, and design of its syringe (two out of six investigators also preferred Belotero ${ }^{\circledR}$ because of the ease of injection) 


\begin{tabular}{|c|c|c|c|}
\hline $\begin{array}{l}\text { Study, design, and } \\
\text { indication }\end{array}$ & Treatments and performance & Pain, safety, and tolerability & $\begin{array}{l}\text { Investigator's and patient's } \\
\text { satisfaction }\end{array}$ \\
\hline $\begin{array}{l}\text { Narins et al }{ }^{35, \mathrm{~b}} \\
\text { Open-label } \\
\text { extension RCT } \\
\text { split-face } \\
\text { NLF }\end{array}$ & $\begin{array}{l}\text { Belotero }{ }^{\circledast} \text { Basic/Balance (vs collagen during } \\
\text { At weeks } 32,48,72 \text {, and } 96 \text {, decrease in } \\
\text { NLF severity on both sides, but greater } \\
\text { with Belotero }{ }^{\circledR} \text { (statistical comparison not } \\
\text { performed) } \\
\text { Mean GAIS score (by investigator) was at } \\
2 \text { (improved) or } 3 \text { (much improved) at all } \\
\text { time points. Better results on Belotero } \\
\text { side (according to either GAIS investigator } \\
\text { or GAIS patient) } \\
\text { Predictors of longevity: } 80.2 \% \text { of patients } \\
\text { persisted without treatment for an interval } \\
\text { of } 48 \text { weeks, regardless of treatment }\end{array}$ & $\begin{array}{l}\mathrm{RCT} \text { ) ( } \mathrm{n}=95 \text { out of the } 106 \text { completers of RCT) } \\
34 \text { AEs reported in } 24.2 \% \text { of patients } \\
\text { Only one AE ( } 2.9 \% \text { ) considered related: } \\
\text { injection-site bruising, on both sides of the face } \\
\text { (moderate severity, resolved within } 3 \text { days) } \\
\text { Antibodies to HA at week } 32 \text { ( } n=79 \text { ): no } \\
\text { detectable anti-HA IgG antibodies in } 86.1 \% \\
\text { of patients; borderline positive in } 10.1 \% \\
\text { (pretreatment) } \\
\text { In the I0.I\%, three patients had positive } \\
\text { anti-HA titers, with only one patient showing } \\
\text { significant increase pre- to posttreatment } \\
\text { Anti-HA IgE antibodies: assays all negative }\end{array}$ & Not assessed \\
\hline \multicolumn{4}{|c|}{ Study design other than RCT } \\
\hline $\begin{array}{l}\text { Observational } \\
\text { study } \\
\text { Facial treatments } \\
\text { (mostly NLF [45\%] } \\
\text { and lip [28\%]) }\end{array}$ & $\begin{array}{l}\text { Performance not formally assessed } \\
\text { No patient returned between months I } \\
\text { and } 3 \text { because of early reabsorption of the } \\
\text { product }\end{array}$ & $\begin{array}{l}\text { Exact count of AEs not provided } \\
\text { Short-term AEs (within I month): swelling, } \\
\text { redness, and bruising (only three AEs lasted for } \\
\geq 24 \text { hours) } \\
\text { No infection, lumps, or product migration } \\
\text { Long-term AEs (ie, persisted for } \geq I \text { month } \\
\text { after injection): no infection, granuloma, } \\
\text { persistent lumps }\end{array}$ & $\begin{array}{l}\text { Of the } 475 \text { patients, } 473 \text { were } \\
\text { satisfied or more than satisfied. } \\
\text { (note: results in contradiction } \\
\text { with the sample size reported in } \\
\text { the methods, } n=448 \text { ) }\end{array}$ \\
\hline Dirting et $\mathrm{al}^{33}$ & \multicolumn{3}{|c|}{ Belotero ${ }^{\circledast}$ Basic ( $n=114$, with 109 completed treatment period, 35 completers of 36 -week follow-up) } \\
\hline $\begin{array}{l}\text { Prospective study } \\
\text { NLF }\end{array}$ & $\begin{array}{l}\% \text { of patients with improvement in WSRS } \\
\text { of } \geq I \text { point: } 100 \% \text { after injection, } 97 \% \text { at } \\
2 \text { and } 4 \text { weeks, } 91 \% \text { at } 12 \text { weeks, and } 81 \% \\
\text { at } 24 \text { weeks } \\
\text { Percentage down to } 66 \% \text { in the } 35 \text { patients } \\
\text { who did the follow-up (other patients } \\
\text { were back to their baseline score) } \\
\text { GAIS by patient: } 82 \% \text { of patients assessed } \\
\text { the esthetic results as improved at } \\
24 \text { weeks }\end{array}$ & $\begin{array}{l}\text { Related AEs in } 61 \% \text { of patients } \\
\text { Most common AEs: hematoma, erythema, } \\
\text { swelling, and induration of mild intensity } \\
\text { No AEs leading to discontinuation } \\
\text { No related SAEs during the study, nor the follow-up } \\
\text { After } 2 \text { weeks, AEs reported in } 23 \% \text { of } \\
\text { patients. After } 6 \text { months, only two AEs } \\
\text { reported (one discoloration, one nodule) } \\
\text { Tolerability considered good/very good by the } \\
\text { investigators in } 96 \% \text { of patients at } 24 \text { weeks }\end{array}$ & Not assessed \\
\hline Kühne et $\mathrm{al}^{38}$ & Belotero ${ }^{\circledR}$ Basic /Balance $(n=3 \mid 7)$ & & \\
\hline $\begin{array}{l}\text { Retrospective } \\
\text { study } \\
\text { Facial treatments }\end{array}$ & Performance not formally assessed & $\begin{array}{l}\text { Most common AEs: erythema, edema, ecchymosis } \\
\text { (all of short duration, count not provided) } \\
\text { No persisting nodules, no granulomas, no } \\
\text { Tyndall effect } \\
\text { No SAEs }\end{array}$ & Not formally assessed \\
\hline Downie et $\mathrm{al}^{34}$ & Belotero ${ }^{\circledR}$ Basic/Balance $(n=93)$ & & \\
\hline $\begin{array}{l}\text { Open-label study } \\
\text { NLF }\end{array}$ & $\begin{array}{l}\text { WSRS: improvement at } 2,4,8,12,16 \text {, } \\
\text { and } 24 \text { weeks for both NLFs, according } \\
\text { to investigator and independent rater. } \\
\text { GAIS: same results as WSRS, based on the } \\
\text { patient's assessment }\end{array}$ & $\begin{array}{l}\text { Related AEs in } 77.4 \% \text { of patients; most frequent } \\
\text { ( }>50 \% \text { of patients): swelling, induration, and } \\
\text { pain at injection site } \\
\text { AEs related to injection in } 32.3 \% \text { of patients; } \\
\text { most frequent ( }>10 \% \text { of patients): bruising } \\
\text { and discoloration. Systemic AEs in } 11.8 \% \text { of } \\
\text { patients, all unrelated. No SAEs }\end{array}$ & Not assessed \\
\hline $\begin{array}{l}\text { Gilbert and } \\
\text { Calvisi }{ }^{42}\end{array}$ & $\begin{array}{l}\text { Belotero }{ }^{\circledast} \text { Balance }(n=I) \text {, Restylane }{ }^{\circledast}+\text { lidoc } \\
\text { lidocaine }(n=3) \text {, Radiesse }{ }^{\circledast}(n=I)\end{array}$ & aine $(n=l)$, Perlane ${ }^{\circledast}+$ lidocaine $(n=1)$, Juvéderm ${ }^{\circledast}$ & Voluma/Volift/Volbella + \\
\hline $\begin{array}{l}\text { Case series } \\
\text { Facial treatments } \\
\text { (mostly mid face } \\
[7 \mid \%])\end{array}$ & $\begin{array}{l}\text { Discussion regarding the choice of each } \\
\text { filler. Performance not reported }\end{array}$ & 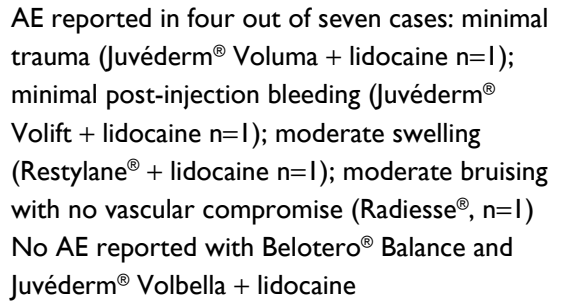 & Not assessed \\
\hline
\end{tabular}


Table 4 (Continued)

\begin{tabular}{|c|c|c|c|}
\hline $\begin{array}{l}\text { Study, design, and } \\
\text { indication }\end{array}$ & Treatments and performance & Pain, safety, and tolerability & $\begin{array}{l}\text { Investigator's and patient's } \\
\text { satisfaction }\end{array}$ \\
\hline & \multicolumn{3}{|l|}{ Belotero ${ }^{\circledR}$ Balance $(n=5)$ and Restylane ${ }^{\circledR}-L(n=5)$} \\
\hline $\begin{array}{l}\text { Retrospective chart } \\
\text { review } \\
\text { Infraorbital hollow }\end{array}$ & $\begin{array}{l}\text { Belotero }{ }^{\circledR} \text { Basic/Balance spread more } \\
\text { widely in the tissue plane, compared to } \\
\text { Restylane }{ }^{\circledR} \\
\text { Belotero }{ }^{\circledR} \text { : "elongated, spindle-shaped } \\
\text { configuration" } \\
\text { Restylane }{ }^{\circledR:} \text { :"bubble or pearl-like configuration" }\end{array}$ & $\begin{array}{l}\text { Only reported } A E \text { : edema, } \sim 2 \text { weeks after } \\
\text { injection (Belotero }{ }^{\circledR} \mathrm{n}=\mathrm{I} \text {; Restylane }{ }^{\circledR} \mathrm{n}=\mathrm{I} \text { ) }\end{array}$ & Not assessed \\
\hline Hevia et $\mathrm{al}^{40}$ & \multicolumn{3}{|l|}{ Belotero ${ }^{\circledR}$ Balance ( $\mathrm{n}=49$, with 46 completers) } \\
\hline $\begin{array}{l}\text { Prospective study } \\
\text { Infraorbital hollow }\end{array}$ & $\begin{array}{l}\text { Decrease in hollowness from baseline } \\
(P<0.00 \mathrm{I}) \\
\text { At } 2 \text { months, an improvement in } \\
\text { hollowness of } \geq I \text { point was seen in } 76.1 \% \\
\text { of patients (and } \geq 2 \text { points in } 19.6 \%) \\
\text { At } 10 \text { months, } 27 \text { out of } 31 \text { ( } 87 \%) \text { patients } \\
\text { still showed an improvement of } \geq I \text { point }\end{array}$ & $\begin{array}{l}\text { Mild-to-moderate delayed swelling }(n=4) \text { at } \\
2 \text { weeks, which resolved within } 2-10 \text { months } \\
\text { Other AEs: erythema, ecchymosis, edema } \\
\text { (count not provided) } \\
\text { No SAEs }\end{array}$ & $\begin{array}{l}\text { Two-thirds of patients did not } \\
\text { elect complimentary additional } \\
\text { treatment at } 6 \text { months (but } \\
\text { remained in the study for } \\
\text { analysis) }\end{array}$ \\
\hline Wollina ${ }^{41}$ & \multicolumn{3}{|c|}{ Belotero ${ }^{\circledR}$ Basic $(n=21)$, Glytone ${ }^{\circledR} 3(n=10)$, and Radiesse ${ }^{\circledR}$ (calcium hydroxyapatite, $\left.n=9\right)$} \\
\hline $\begin{array}{l}\text { Retrospective } \\
\text { study } \\
\text { Tear trough }\end{array}$ & $\begin{array}{l}\text { I00\% of patients improved after the first } \\
\text { procedure, two patients needed a touch-up } \\
\text { Average improvement: I class on the } \\
\text { Hirmand's classification; I } 2 \text { patients } \\
\text { originally in Class II had a } 2 \text {-class } \\
\text { improvement } \\
\text { Duration of effect: between } 9 \text { and } 12 \text { months } \\
\text { with HA fillers ( } 10.1 \pm 2.4 \text { months), and } \\
\text { between II and I5 months with Radiesse }{ }^{\circledR} \\
\text { ( } 12.8 \pm 3.9 \text { months) }\end{array}$ & $\begin{array}{l}\text { AEs in } 25 \text { out of } 31 \text { patients }(80.6 \%) \text { with HA } \\
\text { fillers (Belotero }{ }^{\circledR} \text { and Glytone }{ }^{\circledR} \text { pooled): bruising } \\
(n=\mid 3) \text {, edema }(n=6) \text {, and redness }(n=6) \\
\text { All AEs mild and temporary; resolved within } \\
2-3 \text { weeks without treatment } \\
\text { No Tyndall effect, bumps, or nodules } \\
\text { Radiesse }{ }^{\circledR} \text { group: AEs in four out of nine } \\
\text { patients }(44.4 \%) \text {, all mild and temporary } \\
\text { (bruising } n=4 \text {, redness } n=2 \text {, edema } n=2)\end{array}$ & $\begin{array}{l}38 \text { out of } 40 \text { patients }(95 \%) \\
\text { were very satisfied with HA } \\
\text { fillers (data not provided for } \\
\text { Belotero }{ }^{\circledR} \text { alone) }\end{array}$ \\
\hline Effect of lidocaine & & & \\
\hline $\begin{array}{l}\text { Moradi et } \text { al }^{31} \\
\text { RCT split-face }\end{array}$ & \multicolumn{3}{|c|}{$\begin{array}{l}\text { Belotero }{ }^{\circledR} \text { Balance }(B E L, n=10) \text {, Belotero }{ }^{\circledR} \text { Balance with lidocaine }(B E L+\text { lido, } n=10) \text {, Belotero }{ }^{\circledR} \text { Balance with lidocaine }+ \\
\text { epinephrine }(B E L+\text { lido }+ \text { epi, } n=10)\end{array}$} \\
\hline Perioral lines & Not assessed & $\begin{array}{l}\text { Most common AEs: bruising and pain } \\
\text { No significant difference in pain and bruising } \\
\text { scores between treatments } \\
\text { No lumps or nodules reported }\end{array}$ & Not assessed \\
\hline $\begin{array}{l}\text { Prager and } \\
\text { Micheels }^{32}\end{array}$ & \multicolumn{3}{|c|}{ Belotero ${ }^{\circledR}$ Basic/Balance with/without lidocaine $(n=29)$, blanching technique used in 21 patients $(72 \%)$} \\
\hline $\begin{array}{l}\text { Prospective survey, } \\
\text { split-face } \\
\text { Facial treatments } \\
\text { (mostly NLF [79\%] } \\
\text { and marionette } \\
\text { lines }[62 \%] \text { ) }\end{array}$ & $\begin{array}{l}\text { Physician's experience: Belotero }{ }^{\circledR} \text { with/ } \\
\text { without lidocaine similar in terms of } \\
\text { ejection force, texture, and placement } \\
\text { Blanching technique with lidocaine: easier } \\
\text { than without lidocaine } n=2 \text {, similar/ } \\
\text { identical } n=19 \\
\text { Same skin distribution of products: } 76 \% \\
\text { applications. Esthetic outcomes rated by } \\
\text { investigator: similar or identical between } \\
\text { products in all patients }\end{array}$ & $\begin{array}{l}\text { Pain reported in } 20 \text { out of } 29 \text { patients, with } \\
\text { lower mean pain intensity with lidocaine } \\
\text { than without lidocaine }(2.8 \pm I . I \text { vs } 5.8 \pm 2 . I \text {, } \\
P=0.000 \mathrm{I}) \\
\text { Redness after injection in } 52 \% \text { of patients with } \\
\text { both products } \\
\text { Bruising after injection in } 10 \% \text { of patients } \\
\text { without lidocaine, and } 14 \% \text { of patients with } \\
\text { lidocaine }\end{array}$ & $\begin{array}{l}\text { Patient-assessed satisfaction } \\
(n=2 I): 2 I \text { patients (I00\%) were } \\
\text { satisfied }\end{array}$ \\
\hline \multicolumn{4}{|c|}{ Belotero $^{\circledR}$ Hydro } \\
\hline \multicolumn{4}{|c|}{ Study design other than RCT } \\
\hline $\begin{array}{l}\text { Open-label study } \\
\text { Periorbital area }\end{array}$ & $\begin{array}{l}\text { Investigator \#I: } 52.6 \% \text { of patients showed } \\
25 \% \text { improvement; Investigators \#2 and } \\
\# 3: \sim 60 \% \text { of patients had a } 25 \% \text { or } 50 \% \\
\text { improvement } \\
\text { Independent rater: } \geq 50 \% \text { of patients } \\
\text { showed } 50 \% \text { improvement }\end{array}$ & $\begin{array}{l}\text { Mild pain during injection in } \sim 80 \% \text { of patients; } \\
\text { one case of severe pain (during the first } \\
\text { session). Injection-site AEs: edema ( } 80 \% \text { of } \\
\text { all sessions, lasting for } 6 \text { days on average), } \\
\text { hematoma (in } 76 \% \text { of patients, lasting for } \\
7 \text { days), erythema (in } 10 \%, 0 \% \text {, and } 30 \% \text { of } \\
\text { patients after sessions I, } 2 \text {, and 3, respectively) } \\
\text { Papules in most patients (lasting for } 5 \text { days). } \\
\text { No SAEs }\end{array}$ & $\begin{array}{l}\text { Patient's satisfaction (from } 0 \text { - } \\
\text { worst to } 10 \text { - best): mean score } \\
\text { of } 5.9 \text { (range: } 0 \text { in I patient to } 8 \\
\text { in } 4 \text { patients) }\end{array}$ \\
\hline
\end{tabular}




\begin{tabular}{|c|c|c|c|}
\hline $\begin{array}{l}\text { Study, design, and } \\
\text { indication }\end{array}$ & Treatments and performance & Pain, safety, and tolerability & $\begin{array}{l}\text { Investigator's and patient's } \\
\text { satisfaction }\end{array}$ \\
\hline \multicolumn{4}{|c|}{ Belotero $^{\circledR}$ Soft (and/or other Belotero ${ }^{\circledR}$ dermal fillers) } \\
\hline Bezzola and & Esthélis ${ }^{\circledR}$ Basic $(n=25)$ and Soft $(n=11)$ & & \\
\hline Micheels $s^{27, c}$ & Soft: performance not formally assessed & No formal count of AEs & Not assessed \\
\hline Open-label study & Basic: persistence of treatment effect over & Based on the physician's experience, AEs & \\
\hline \multirow[t]{4}{*}{ Facial treatments } & time, ranging from 3 to 7 months in the & to be expected are: minor edema, bruising/ & \\
\hline & 25 patients & hematoma, post-injection erythema lasting for & \\
\hline & & $\leq 48-72$ hours & \\
\hline & & No infection, granuloma, or allergy reported & \\
\hline Micheels ${ }^{26, c}$ & \multicolumn{3}{|c|}{ Esthélis ${ }^{\circledR}$ Basic and Soft ( $n=13$, out of the 36 included in the pilot study) } \\
\hline Safety follow-up & Not assessed & AEs: rare bruises, erythema ( $\leq 24$ hours), very & Not assessed \\
\hline \multirow[t]{3}{*}{ Facial treatments } & & light swelling ( $\leq 24$ hours) (exact count of AEs & \\
\hline & & not provided) & \\
\hline & & No allergic reaction or granuloma & \\
\hline Hasson and & \multicolumn{3}{|l|}{ Esthélis ${ }^{\circledR}$ Basic or Soft $(n=12)$} \\
\hline \multicolumn{4}{|l|}{ Romero ${ }^{25}$} \\
\hline Prospective study & Esthetic improvement rated by the & Mild or moderate pain during injection & Not assessed \\
\hline \multirow{8}{*}{$\begin{array}{l}\text { Facial atrophic } \\
\text { scars }\end{array}$} & investigator as moderate $(27 \%)$, good & Mild erythema immediately after injection & \\
\hline & $(57 \%)$, or excellent (17\%) immediately, & (count not reported); resolved spontaneously & \\
\hline & I week, and I month after injection. & within a few hours. No Tyndall effect & \\
\hline & Patient's rating: moderate ( $17 \%)$, good & & \\
\hline & (33\%), or excellent $(50 \%)$ immediately & & \\
\hline & after injection, and good (42\%) or & & \\
\hline & excellent (58\%) I week and I month after & & \\
\hline & injection & & \\
\hline Pavicic et $\mathrm{al}^{30}$ & \multicolumn{3}{|c|}{ Belotero $^{\circledast}$ (Soft/Basic/Intense) after Bocouture ${ }^{\circledast}$ (botulinum toxin) and Radiesse ${ }^{\circledR}$ (calcium hydroxyapatite)/[Bocouture ${ }^{\circledast}+$} \\
\hline Case series & \multirow{2}{*}{\multicolumn{3}{|c|}{$\begin{array}{l}\left.\text { Radiesse }{ }^{\circledast}\right]+ \text { Belotero }{ }^{\circledR} \text { Soft, Basic, and Intense (Patient A), Belotero }{ }^{\circledR} \text { Basic and Intense (Patient B), or Belotero }{ }^{\circledR} \text { Soft and } \\
\text { Basic (Patient C) }\end{array}$}} \\
\hline Whole-face & & & \\
\hline rejuvenation & $\begin{array}{l}\text { At I I-I } 4 \text { days after last treatment, } \\
\text { improvement of } \geq I \text { point: nine out of } \\
\text { eleven sites }(82 \%) \text { in Patients A and C, ten } \\
\text { out of eleven sites }(91 \%) \text { in Patient B }\end{array}$ & $\begin{array}{l}\text { Procedure well tolerated (detailed safety } \\
\text { results not provided) }\end{array}$ & Not formally assessed \\
\hline \multicolumn{4}{|c|}{ Belotero $^{\circledast}$ Intense } \\
\hline \multicolumn{4}{|c|}{ RCT with comparator(s) } \\
\hline Buntrock et al' ${ }^{19}$ & \multicolumn{3}{|l|}{ Belotero ${ }^{\circledR}$ Intense vs Perlane ${ }^{\circledast}(n=20)$} \\
\hline NLF & 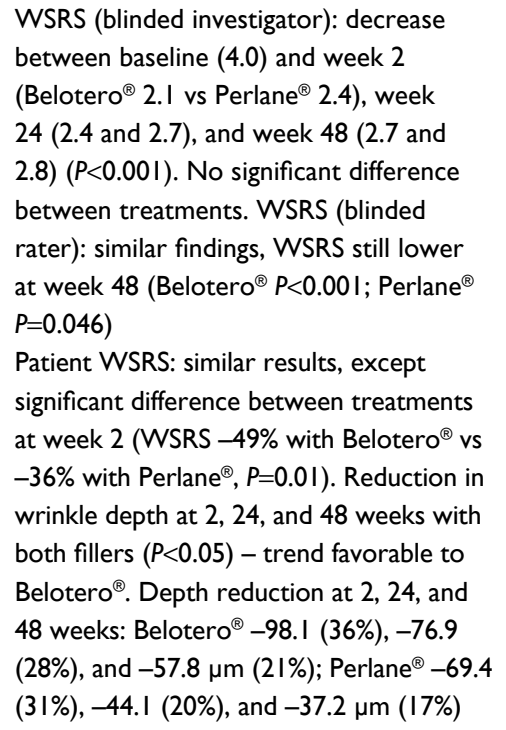 & $\begin{array}{l}\text { Pain after injection lower with Belotero }{ }^{\circledast} \text { than } \\
\text { Perlane }{ }^{\circledR}(3.9 \text { vs } 5.0, P=0.0 I \text { ) } \\
\text { Short-term AEs (within the first } 10 \text { days): mild- } \\
\text { to-severe bruising, redness, swelling, pain, mild- } \\
\text { to-moderate tenderness, nodules, and itching } \\
\text { (count not provided). Similar distribution of } \\
\text { AEs with the two treatments } \\
\text { No SAEs, no AEs leading to discontinuation }\end{array}$ & $\begin{array}{l}\% \text { of patients satisfied higher } \\
\text { with Belotero }{ }^{\circledR} \text { than Perlane }{ }^{\circledR} \text { at } \\
\text { week } 24(62 \% \text { vs } 51 \%, P=0.002) \\
\text { and week } 48(43 \% \text { vs } 33 \%, \\
P=0.005) \\
80 \% \text { of patients would repeat } \\
\text { treatment with Belotero }{ }^{\circledR} \text { vs } \\
65 \% \text { of patients with Perlane }{ }^{\circledR}\end{array}$ \\
\hline \multicolumn{4}{|c|}{ Study design other than RCT } \\
\hline Pavicic et $\mathrm{al}^{29}$ & \multicolumn{3}{|c|}{ Belotero ${ }^{\circledR}$ Basic and Belotero ${ }^{\circledR}$ Intense combined $(n=2)$} \\
\hline Case series & $\begin{array}{l}\text { Case I: at } 30 \text { months, no facial lipoatrophy } \\
\text { and no NLF visible (just lines) }\end{array}$ & $\begin{array}{l}\text { Case I: mild erythema but no edema, } \\
\text { hematoma, or other AEs after first injection }\end{array}$ & Case I: not reported \\
\hline
\end{tabular}


Table 4 (Continued)

\begin{tabular}{|c|c|c|c|}
\hline $\begin{array}{l}\text { Study, design, and } \\
\text { indication }\end{array}$ & Treatments and performance & Pain, safety, and tolerability & $\begin{array}{l}\text { Investigator's and patient's } \\
\text { satisfaction }\end{array}$ \\
\hline $\begin{array}{l}\text { HIV-associated } \\
\text { facial lipoatrophy }\end{array}$ & $\begin{array}{l}\text { Case 2: I month after first injection, } \\
\text { lipoatrophy at grade } 0 \text {-I; } 8 \text { months later, loss } \\
\text { of filling effect - second injection, I0 days } \\
\text { later lipoatrophy grade I; at } 20 \text { months, } \\
\text { lipoatrophy grade } 2-3 \text { - third injection; at } \\
26 \text { months, lipoatrophy at grade } 0\end{array}$ & $\begin{array}{l}\text { Case 2: no AEs after the first injection, } \\
\text { injection-site erythema after the second } \\
\text { injection (resolved within I day). In both cases, } \\
\text { no difference between the two fillers regarding } \\
\text { pain and other AEs }\end{array}$ & $\begin{array}{l}\text { Case 2: fully satisfied I month } \\
\text { after first injection and } 10 \text { days } \\
\text { after second injection }\end{array}$ \\
\hline Micheels ${ }^{45}$ & Fortélis ${ }^{\circledR}$ Extra $(n=28$, histology $n=1)$ & & \\
\hline $\begin{array}{l}\text { Observational } \\
\text { study (+ histology) }\end{array}$ & $\begin{array}{l}\text { At } 6 \text { months, clinical improvement for all } \\
\text { treated areas (not quantified) }\end{array}$ & $\begin{array}{l}\text { Erythema and mild edema }(n=I) \text {, translucent cord } \\
(n=I) \text {, overcorrection in the lip }(n=I) \text {, slightly }\end{array}$ & $\begin{array}{l}\text { Two patients were not satisfied: } \\
\text { injected volume too large in the }\end{array}$ \\
\hline Facial treatments & $\begin{array}{l}\text { At } \geq 10 \text { months, improvement persisted } \\
\text { for most patients (not quantified) }\end{array}$ & $\begin{array}{l}\text { asymmetrical injection with a mild edema }(n=1) \\
\text { No delayed inflammatory reaction at } \\
12 \text { months. Histology on day } 90 \text { : no } \\
\text { inflammatory reaction or fibrosis }\end{array}$ & $\begin{array}{l}\text { lip ( } 1.5 \mathrm{~mL}) \text {, injection slightly } \\
\text { asymmetrical }\end{array}$ \\
\hline Pavicic $^{28}$ & \multicolumn{3}{|c|}{ Belotero ${ }^{\circledR}$ Intense alone $(\mathrm{n}=110)$ or combined with Belotero ${ }^{\circledR}$ Basic (sandwich procedure, $\mathrm{n}=39$ ) } \\
\hline Open-label study & WSRS improved after injection (3.98-2.28, & Results pooled for the 149 patients & Esthetic outcomes rated by \\
\hline Facial treatments & $P<0.001)$, with no decline over 12 weeks & Injection-site pain was mild (mean score of & physician as good/excellent in \\
\hline (mostly NLF [84\%]) & $\begin{array}{l}\text { GAIS immediately after injection: } 89.9 \% \\
\text { achieved improvement, of whom } 59.7 \% \\
\text { much/very much improved } \\
\text { Effect well maintained throughout the } \\
\text { three-month study }\end{array}$ & $\begin{array}{l}2.7 \text { on VAS). Post-injection AEs in } 85.9 \% \text { of } \\
\text { patients, mostly related to injection procedure } \\
\text { Most common AEs: erythema ( } 63.8 \%) \text {, swelling } \\
(52.3 \%) \text {, pain }(49.7 \%) \text {, hematoma }(27.5 \%) \text {, } \\
\text { induration }(21.5 \%)\end{array}$ & $\begin{array}{l}83.3 \% \text { of patients at } 12 \text { weeks. } \\
\text { After injection, excellent/good } \\
\text { satisfaction in } 94 \% \text { of patients } \\
\text { and } 90.6 \% \text { of investigators (nearly } \\
\text { maintained over } 12 \text { weeks) }\end{array}$ \\
\hline
\end{tabular}

Belotero ${ }^{\circledR}$ Volume

Study design other than RCTs

Micheels et $\mathrm{al}^{47}$

Belotero ${ }^{\circledR}$ Volume $(n=56)$

Observational

FVLS scores improved from moderate

study at baseline to mild at 6 months with

Facial volume

loss (mostly

cheeks [38.6\%],

cheekbones improvements of $53 \%, 57 \%$, and $74 \%$ for

Only injection-site AEs

On day I, AEs in 14 patients (25\%): swelling $n=5$, bruising $n=3$, redness $n=2$, pain $n=2$,

the cheeks (3.5-I.6), cheek bones (3.8-I.6), induration $n=2$. At month I, AEs in five

Becker et $\mathrm{al}^{21}$ Observational study HIV-associated facial lipoatrophy

Micheels et $\mathrm{al}^{46}$ Post-marketing clinical follow-up Age-related mid face atrophy and tear trough (3.8-1.0), respectively GAIS by investigator: improvement at 6 months for all indications, more particularly for the cheeks (I.I3) and tear trough (I.75). Cheekbones also responded well (2.0) GAIS by patients: "improved" to "very much improved"; from day I to 6 months

Modélis ${ }^{\circledR}$ Shape $(n=10)$ MRI: HA volume $+331 \%$ at I month $(P<0.000 \mathrm{I})$, with no reduction at 12 months; skin thickness and tissue vascularization increased during the first 6 months. GAIS: very much improved $n=2$, much improved $n=5$, improved $n=3$ patients (8.9\%): swelling $n=4$, induration $n=1$ At month 3, AEs in five patients (8.9\%): swelling $n=3$, induration $n=1$, discoloration $n=1$ All mild except pain on day I, one case of swelling at month I, and discoloration at month 3 (all moderate)

Slight erythema after injection $n=2$ (resolved in 2-3 days)

No skin hyperpigmentation, no pain, no itching No swelling, discomfort, or induration after injection

No allergic reaction, no product-related complications

Modélis ${ }^{\circledR}$ Shape/Belotero ${ }^{\circledR}$ Volume ( $n=20$, with eleven completers at month I8) Investigator's FVLS: mean score 3.I at baseline, I.3 immediately after injection, I.3-I.8 between month I and month I8 $(P<0.000 \mathrm{I})$ Investigator's GAIS: immediately after injection and up to month $6, \geq 94 \%$ of patients rated as very much/much improved; $\geq 65 \%$ from months 9 to 18 Patient's GAIS: corresponding \% were $\geq 83 \%$ immediately after injection up to month 6 , and $\geq 50 \%$ from months 9 to 18
Mild or moderate injection-site reaction ( $n=13$ out At month 12, 95\% of patients of $20,65 \%)$ Most frequent AEs on day I: redness were satisfied (ie, would repeat $(n=5,25 \%)$, pain $(n=6,30 \%)$, edema $(n=3,15 \%)$ Also transient bruising $(\mathrm{n}=\mathrm{I}, 5 \%)$ and itching At month 18, 100\% of patients $(n=I, 5 \%)$. Firmness $(n=5,25 \%)$, which resolved (I I/II) satisfied within 3 months
All investigators reported that the volumizing effect was similar to $(50 \%)$ or better than $(50 \%)$ other volumizers. Injections rated as easy/very easy (50\%) or equivalent to other products (40\%)

All patients reported they wanted to pursue treatment
Patient's satisfaction (QoL from 0 to 100): baseline $68.0 \pm 24.0$, 12 months $83.5 \pm 7.4(+15.5 \%$, $P=0.04$ ) treatment) 


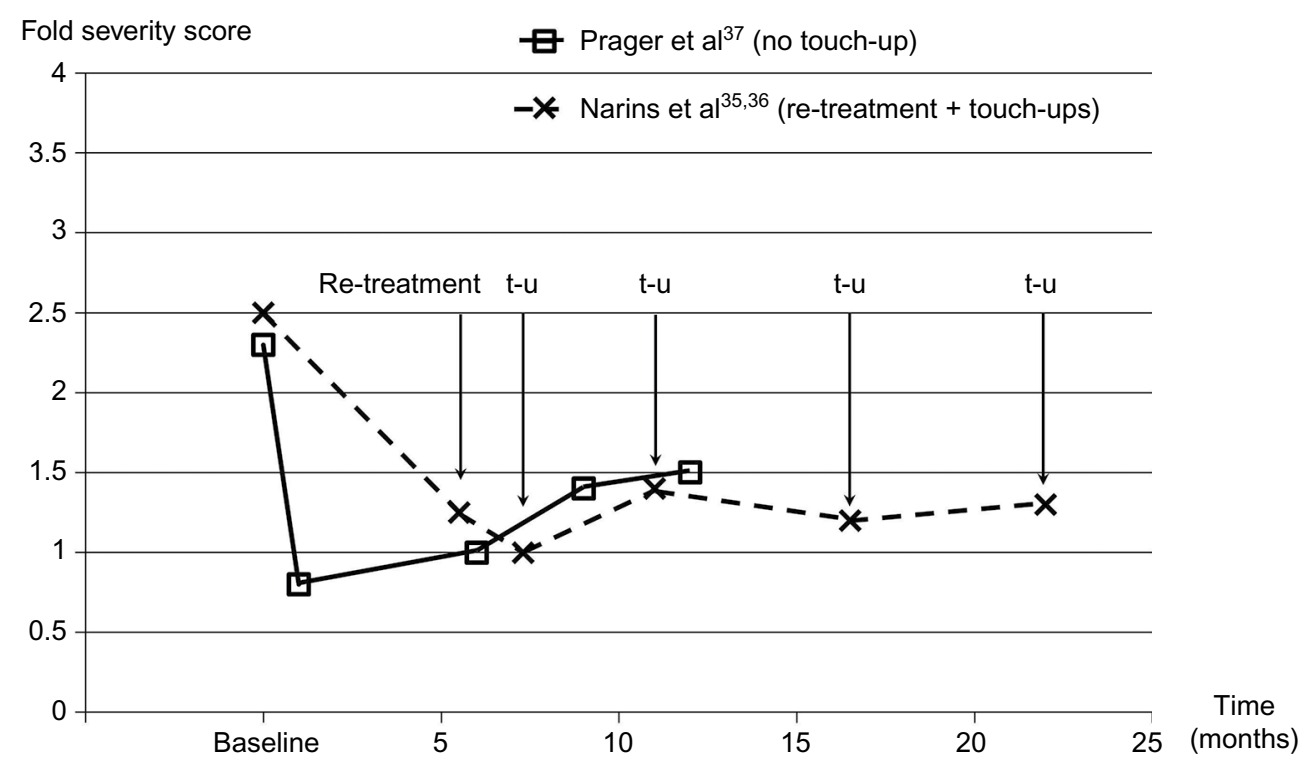

Figure 2 Change in nasolabial fold severity with Belotero ${ }^{\circledR}$ Basic/Balance treatment, re-treatment, and optional touch-ups.

Notes: In Prager et al's study, ${ }^{37}$ fold severity was rated using the Merz Aesthetics Scales at baseline and at I, 6, 9, and I 2 months. In Narins et al's study, ${ }^{35,36}$ fold severity was rated using the Wrinkle Severity Rating Scale at baseline and at 24, 32, 48, 72, and 96 weeks. Baseline is before the injection. Data from Narins et al, ${ }^{35}$ Narins et al, ${ }^{36}$ and Prager et al. ${ }^{37}$

Abbreviation: $\mathrm{t}-\mathrm{u}$, touch-up allowed.

Basic/Balance and collagen. The average time ( \pm standard deviation) between injections during the extension study was $37.0 \pm 15.6$ weeks with Belotero ${ }^{\circledR}$ Basic/Balance and $30.9 \pm 13.6$ weeks with collagen. ${ }^{35}$ Based on these data, the effects of Belotero ${ }^{\circledR}$ Basic/Balance treatment of NLFs seem to persist for 8-12 months.

In a large-scale uncontrolled prospective study conducted in 114 patients who underwent NLF filling, treatment success was obtained in $100 \%$ of patients after injection, $91 \%$ at 12 weeks, and $81 \%$ at 24 weeks (Table 4 ). ${ }^{33}$ Treatment success was defined as an improvement on the WSRS of 1 point or more, which was considered clinically relevant.

These positive findings, which were obtained in a majority of Caucasian patients with Fitzpatrick skin type II or III, were confirmed in patients with Fitzpatrick skin types IV, V, and VI ( $n=93)$, also for the filling of NLFs (Table 4). ${ }^{34}$

\section{Other skin areas/indications}

In 49 patients who had injection of Belotero ${ }^{\circledR}$ Basic/Balance in the infraorbital hollow, an improvement in hollowness of at least 1 point was observed in $76.1 \%$ of patients at 2 months, an improvement which was maintained in $87 \%$ (27 out of 31 ) of patients at 10 months. ${ }^{40}$ In 40 patients who were injected Belotero ${ }^{\circledR}$ Basic/Balance in the tear trough, the average improvement in fold severity at 2-3 weeks was 1 point, and the average treatment longevity was $10.1 \pm 2.4$ months. $^{41}$

Both studies indicate that the injection of Belotero ${ }^{\circledR}$ Basic/ Balance in facial folds other than NLFs leads to a short-term improvement in fold severity of at least 1 point in the majority of patients, and that treatment longevity approximates at least 10 months, which is relatively similar to what was reported for NLF treatment.

The results of the study on atrophic scars ${ }^{25}$ are discussed in the "Belotero ${ }^{\circledR}$ Soft" section. The other studies where Belotero ${ }^{\circledR}$ Basic/Balance was investigated were focused on the safety of the product, ${ }^{26,38}$ the reduction of pain by the addition of lidocaine, ${ }^{31,32}$ or did not formally assess the performance of the filler. ${ }^{39,42}$

\section{Tolerability and safety of Belotero ${ }^{\circledR}$ Basic/Balance Pain}

In the 4-week RCT, pain recorded immediately after injection was lower with Belotero ${ }^{\circledR}$ Basic/Balance than with Restylane ${ }^{\circledR}$ (both being lidocaine-free). Both treatments scored slightly over 6 on the 11-point scale (Table 3 ), without a statistically significant difference between treatments. ${ }^{9}$

To further decrease the pain experienced during and immediately after injection, lidocaine was recently added to Belotero ${ }^{\circledR}$ Basic/Balance (April 2014). Significant pain relief was demonstrated in a split-face trial, with pain intensity going from 5.8 \pm 2.1 without lidocaine to $2.8 \pm 1.1$ with lidocaine, on the 11-point scale $(P=0.0001) .{ }^{32}$ Milder and nonstatistically significant benefits were observed in a parallel-group trial, with mean pain scores (on each side of the face) following injection slightly lower with lidocaine (3.6-3.8 without epinephrine, 3.6-4.6 with epinephrine) than without lidocaine (4.5-5.3). ${ }^{31}$ 


\section{Adverse events}

The majority of adverse events (AEs) related to Belotero ${ }^{\circledR}$ treatment (ie, product or injection procedure) are injectionsite AEs of mild or moderate intensity. ${ }^{36}$

Based on the studies with a large sample size $(>90$ patients), the percentage of patients reporting related AEs with Belotero ${ }^{\circledR}$ ranged from $61 \%$ (70 out of 114$)^{33}$ to $77.4 \%$ (72 out of 93$).^{34}$

The most frequently reported injection-site AEs were erythema/redness, ${ }^{9,33,34,36-41}$ edema/swelling, ${ }^{33,34,36-41}$ and hematoma/bruising, ${ }^{9,34,36-41}$ with an incidence ranging from $2.5 \%$ up to $>50 \%$ (Table 2 ). Other common injection-site AEs included induration, discoloration, nodule, pruritus, and pain.

Injection-site AEs are generally of short duration, the majority resolving in no more than 7 days..$^{34,36,38,39}$ More rarely, these AEs last for $2-3$ weeks ${ }^{41}$ or several months. ${ }^{40}$ They tend to occur shortly after injection, although cases of delayed swelling (ie, 2 weeks after injection) have been reported. ${ }^{22,40}$ Bruising, nodules, swelling, and induration were the injection-site AEs that lasted longer than a week in $>10 \%$ of the 118 patients enrolled in the 6-month RCT. ${ }^{36}$

Regarding injection-site bruising, the addition of epinephrine (as a vasoconstrictor agent) to Belotero ${ }^{\circledR}$ Basic/Balance containing lidocaine did not reduce bruising. ${ }^{31}$

Severe AEs have been reported relatively rarely (Table 4). In the 6-month RCT $(\mathrm{n}=118)$, the severe AEs considered related to the procedure with Belotero ${ }^{\circledR}$ were swelling $(6.8 \%)$ and bruising (8.5\%). ${ }^{36}$ Of the severe AEs considered related to Belotero ${ }^{\circledR}$ itself, injection-site nodule was the only event reported in $>5 \%$ of patients $(5.9 \%) .{ }^{36} \mathrm{~A}$ severe AE of pain has also been reported (in one out of 40 patients treated with Belotero $\left.^{\circledR}\right) .{ }^{37}$

No treatment-related serious adverse events (SAEs) and no AEs leading to discontinuation have been reported in any of the reviewed papers presenting safety data on Belotero ${ }^{\circledR}$ Basic/Balance. There were no reports of persisting nodules, granulomas, or Tyndall effect. ${ }^{38}$

Belotero ${ }^{\circledR}$ was also found to be safe in Fitzpatrick skin types IV-VI (Table 4). ${ }^{34}$

No major differences in safety profiles were observed in head-to-head comparisons between Belotero ${ }^{\circledR}$ Basic/ Balance and collagen, ${ }^{36}$ and other HA fillers (Restylane ${ }^{\circledR}$ or Juvéderm $\left.{ }^{\circledR}\right) \cdot{ }^{9,37}$

\section{Long-term tolerability}

During the 2-year safety follow-up in 13 patients treated with either Belotero ${ }^{\circledR}$ Soft or Basic/Balance, no delayed AEs and no allergic reactions were reported. ${ }^{26}$
Repeated Belotero ${ }^{\circledR}$ injections over time were also well tolerated, with no inflammatory reactions or granulomas reported. ${ }^{26,35}$ In the open-label extension study on correction of NLFs, where repeat injections were given over an 18-month follow-up period, injection-site bruising was the only AE that was considered related to Belotero ${ }^{\circledR} .{ }^{35}$ The measurement of HA antibodies revealed that $86.1 \%$ of patients $(n=79)$ had no detectable anti-HA IgG antibodies and 100\% had no anti-HA IgE antibodies. ${ }^{35}$ Only three patients had positive anti-HA titers, but only one of them showed an increase from pre- $(<400 \mathrm{ng} / \mathrm{mL})$ to posttreatment $(3,487 \mathrm{ng} / \mathrm{mL})$. The authors concluded that Belotero ${ }^{\circledR}$ has little potential for immunogenic reactions. ${ }^{35}$

As a comparison, a similar study had been done in 425 patients who received Restylane ${ }^{\circledR}$ and/or Perlane ${ }^{\circledR}$ (manufactured with $\left.\mathrm{NASHA}^{\circledR}\right) .{ }^{43}$ All anti-NASHA ${ }^{\circledR}$ IgE tests were negative. Serologically, $91.8 \%(n=390)$ of patients were negative for anti-NASHA ${ }^{\circledR}$ IgG. One patient had a four-fold increase in anti-Restylane ${ }^{\circledR} \operatorname{IgG}$ after injection but reported no AEs other than headache on the day after injection. $^{43}$

\section{Patients' and investigators' satisfaction with Belotero ${ }^{\circledR}$ Basic/Balance}

In the 6-month RCT vs collagen, Belotero ${ }^{\circledR}$ Basic/Balance was preferred to collagen by $\sim 80 \%$ of the patients $(n=107)$ and five out of six investigators (in particular due to its storage, handling, and comfort and design of its syringe). ${ }^{36}$ The patients' satisfaction rate was higher with Belotero ${ }^{\circledR}$ Basic/Balance (78.2\%) than with collagen (65.1\%, $P<0.001){ }^{36}$

The results were more equivocal when comparing the patient's satisfaction with different HA fillers at 4 weeks. ${ }^{37}$ In a two-arm split-face trial, approximately half the patients found both fillers acceptable or did not state a preference (13 out of 20 in Arm A, five out of 20 in Arm B). Among those who had a preference, five out of $20(25 \%)$ patients preferred Belotero $^{\circledR}$, while two out of $20(10 \%)$ preferred Restylane ${ }^{\circledR}$ in Arm A, and eight out of 20 (40\%) preferred Belotero ${ }^{\circledR}$, while seven out of $20(35 \%)$ preferred Juvéderm ${ }^{\circledR}$ Ultra 3 in Arm B (Table 4).

\section{Belotero ${ }^{\circledR}$ Hydro}

Belotero $^{\circledR}$ Hydro, in contrast to the other Belotero ${ }^{\circledR}$ fillers, is a non-crosslinked product (Table 1). It is indicated for skin hydration, as well as improvement of skin elasticity and firmness. This product has been tested in one study for the rejuvenation of the periorbital area. ${ }^{44}$ 


\section{Performance of Belotero ${ }^{\circledR}$ Hydro}

After three monthly injections in the periorbital area, the three investigators and a blinded rater assessed the skin appearance (brightness, texture, and turgor) and rated the improvement using a discrete scale $(100 \%, 90 \%, 75 \%$, $50 \%$, or $25 \%$ improvement, no improvement, or worsening of the skin). In general, the investigators' ratings ranged from $25 \%$ to $50 \%$ improvement, while the independent rater considered that more than half the patients showed a $50 \%$ improvement. None of the patients had a worsening of the skin appearance. ${ }^{44}$

\section{Tolerability and safety of Belotero ${ }^{\circledR}$ Hydro \\ Pain}

Approximately $80 \%$ of patients reported mild tolerable pain during injection, with only one case of severe pain. ${ }^{44}$ Injection was performed in the superficial dermis with a $30 \mathrm{G}$ needle, using the micropuncture technique (Table 2).

\section{Adverse events}

Reported AEs were injection-site AEs, most frequently medium-sized papules, edema, and hematoma (in $>70 \%$ of patients), and less frequently erythema (in $\leq 30 \%$ of patients), all of which resolved within 7 days. There were no SAEs.

\section{Patients' and investigators' satisfaction with Belotero ${ }^{\circledR}$ Hydro}

Two weeks after the third injection (ie, at 2.5 months), the mean score given to Belotero ${ }^{\circledR}$ Hydro by the patients was 5.9, on a scale from 0 (worst result) to 10 (best result). ${ }^{44}$

\section{Belotero ${ }^{\circledR}$ Soft}

Belotero ${ }^{\circledR}$ Soft has been tested in four studies, either for facial treatments ${ }^{26,27,30}$ or for treatment of atrophic scars. ${ }^{25}$ Following the first pilot study conducted on Belotero ${ }^{\circledR}$ Soft, ${ }^{27}$ a 24-month safety follow-up has been published. ${ }^{26}$ In all these studies, other Belotero ${ }^{\circledR}$ dermal fillers were tested (Basic/Balance, ${ }^{25-27}$ whole Belotero ${ }^{\circledR}$ range $^{30}$ ), and the results of Belotero ${ }^{\circledR}$ Soft were pooled with those of other fillers (Table 2).

\section{Performance of Belotero ${ }^{\circledR}$ Soft}

In the pilot study ${ }^{27}$ and its 24-month safety follow-up ${ }^{26}$ where patients received facial treatments, the performance of Belotero ${ }^{\circledR}$ Soft was not formally assessed (Table 4).

In the 12 patients treated for atrophic scars with either Belotero $^{\circledR}$ Soft or Belotero ${ }^{\circledR}$ Basic/Balance, the esthetic improvement was rated as good or excellent by $74 \%$ of investigators and $100 \%$ of patients, 1 week and 1 month after injection (Table 4). ${ }^{25}$
In the three patients who underwent facial rejuvenation with a sequential approach (botulinum toxin followed by calcium hydroxyapatite a month later and HA filler 2 or 4 weeks later), fold severity improved at almost all treated sites 11-14 days after the last treatment. The injection of Belotero $^{\circledR}$ (last treatment in the sequential approach) led to further improvement in the esthetic outcomes in six out of eleven treated sites in all three patients. ${ }^{30}$

\section{Tolerability and safety of Belotero ${ }^{\circledR}$ Soft \\ Pain}

Pain during injection was rated as mild or moderate by the patients treated for atrophic scars. ${ }^{25}$

\section{Adverse events}

No study reported the exact count of AEs with Belotero ${ }^{\circledR}$ Soft. Mild erythema immediately after injection has been reported in the study on atrophic scars; however, the event resolved spontaneously within a few hours. ${ }^{25}$ In the 2-year safety follow-up ${ }^{26}$ of the pilot study, ${ }^{27}$ rare bruises have been reported with the $30 \mathrm{G}$ needle, along with short-lasting erythema (resolving within 24 hours, also reported by Hasson and Romero ${ }^{25}$ ) and very light swelling immediately after injection. Based on these findings, Belotero ${ }^{\circledR}$ Soft may be injected safely with predictable results in easily swollen and thin skin areas such as the periorbital area (Figure 3). Importantly, no allergic reactions and no granulomas have been reported during the 2-year follow-up. Altogether, these findings suggest that the reactions to Belotero ${ }^{\circledR}$ Soft were related to the injection procedure rather than the product itself.

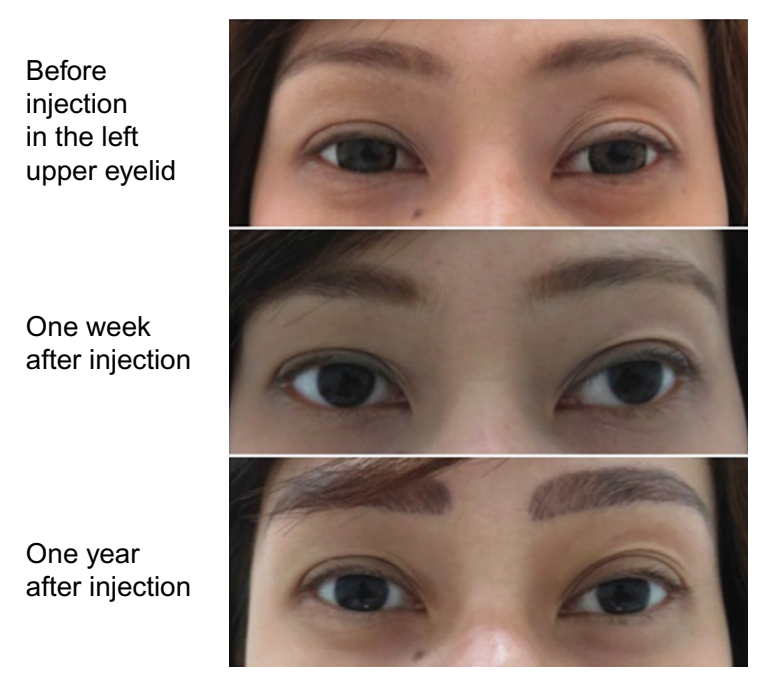

Figure 3 Esthetic effect of Belotero ${ }^{\circledR}$ Soft.

Notes: A 30-year-old female patient with congenital unilateral (left) upper eyelid hollowness received $0.2 \mathrm{~mL}$ of Belotero ${ }^{\circledR}$ Soft in the suborbicularis fibroadipose tissue (pre-septal) layer using a blunt tip cannula to prevent bruising and intravascular injection. The product was spread as a thin layer to avoid swelling and lumps. Photo courtesy of AD Prasetyo. 


\section{Patients' and investigators' satisfaction with Belotero ${ }^{\circledR}$ Soft}

Following the first sessions of treatment with either Belotero ${ }^{\circledR}$ Soft or Belotero ${ }^{\circledR}$ Basic/Balance, ${ }^{27}$ most of the 13 patients who participated in the safety follow-up had further treatments performed during the 2 following years (on the same area or other areas), ${ }^{26}$ suggesting a general satisfaction with the procedure.

\section{Belotero ${ }^{\circledR}$ Intense}

Among the five studies that investigated the use of Belotero ${ }^{\circledR}$ Intense, one was focused on NLFs ${ }^{19}$ (the only RCT), two on various facial treatments of deep lines and wrinkles, ${ }^{28,45}$ one on two cases of HIV-associated facial lipoatrophy, ${ }^{29}$ and one on whole-face rejuvenation using a combination offillers. ${ }^{30}$

\section{Performance of Belotero ${ }^{\circledR}$ Intense}

One RCT using a split-face design has been conducted on Belotero ${ }^{\circledR}$ Intense, with the HA filler Perlane ${ }^{\circledR}$ as a comparator $(n=20)$, to treat NLF rated as moderate to severe at baseline. ${ }^{19}$

In this 48-week trial, the mean reduction in wrinkle depth at 2, 24, and 48 weeks was significant with both treatments $(P<0.05)$ and was greater (although not statistically significantly) with Belotero ${ }^{\circledR}$ Intense $(-98.1,-76.9$, and $-57.8 \mu \mathrm{m}$, respectively) than with Perlane ${ }^{\circledR}(-69.4,-44.1$, and $-37.2 \mu \mathrm{m}$, respectively), as assessed by skin topography (phase-shift rapid in vivo measurement of skin).
The difference between treatments reached statistical significance when considering the reduction in WSRS at 2 weeks, when assessed by the patient $\left(-49 \%\right.$ with Belotero ${ }^{\circledR}$ Intense vs $-36 \%$ with Perlane $\left.{ }^{\circledR}, P=0.01\right)$. The reduction in WSRS scores was also significant at 24 and 48 weeks, for both fillers $(P<0.001)$.

In a large open-label study $(\mathrm{n}=149)$, Belotero ${ }^{\circledR}$ Intense has been tested, either on its own or after injection of Belotero ${ }^{\circledR}$ Basic/Balance. In the second case, the procedure is referred to as the "sandwich technique", which generally describes injections performed in two different depths or more (superficial-to-deep dermal injection). ${ }^{28}$ The assessment of WSRS post-injection, at 2 and 12 weeks confirms the findings of the 48-week RCT. The WSRS score was significantly reduced at all time points $(P<0.001)$, with the lowest value obtained at 2 weeks. The combined results of both studies are presented in Figure 4. The maintenance of the treatment effect over 12 weeks was confirmed by the investigator's GAIS ratings, with $59.7 \%$ and $57.0 \%$ of patients considered as much/very much improved at 2 and 12 weeks, respectively. ${ }^{28}$ The esthetic effect of the filler was rated as good or excellent in $83.3 \%$ of patients.

Regarding treatment longevity, mean wrinkle depth and WSRS scores were still lower, and the patient's satisfaction was still higher, up to 48 weeks ( 11 months) after injection $(P<0.001$, Figure 4). ${ }^{19} \mathrm{~A}$ 1-year follow-up study in 28 patients treated on different facial areas also indicated that the esthetic effect of Belotero $^{\circledR}$ Intense remained clinically relevant for $9-12$ months. ${ }^{45}$

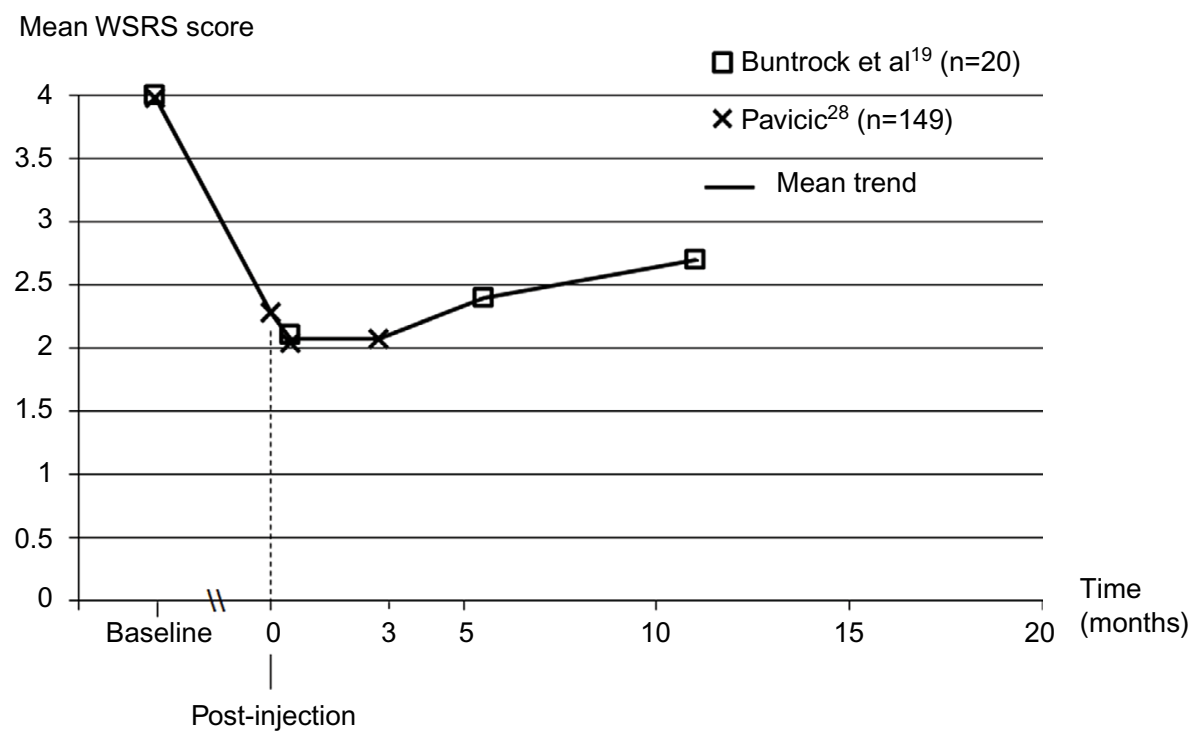

Figure 4 Long-term change in nasolabial fold severity with Belotero ${ }^{\circledR}$ Intense treatment based on the investigators' rating on the Wrinkle Severity Rating Scale.

Notes: The difference from baseline was statistically significant at each time point, in both studies $(P<0.00 \mathrm{I})$. The mean trend shows the average scores when pooling data from the two studies. In Buntrock et al's study, ${ }^{19}$ the ratings were performed by a blinded investigator at baseline (ie, before injection) and at 2 , 24 , and 48 weeks. In Pavicic's study, ${ }^{28}$ the ratings were performed by an unblinded investigator at baseline, immediately post-injection, and then at 2 and 12 weeks. In both studies, touch-ups were not allowed. Data from Buntrock et al. ${ }^{19}$ Adapted from Pavicic T. Efficacy and tolerability of a new monophasic, double-crosslinked hyaluronic acid filler for correction of deep lines and wrinkles. J Drugs Dermatol. 201 I; I0(2): I34-139. ${ }^{28}$

Abbreviation: WSRS, Wrinkle Severity Rating Scale. 


\section{Other skin areas/indications}

Two patients with HIV-associated facial lipoatrophy were treated with a combination of Belotero ${ }^{\circledR}$ Basic/Balance and Belotero ${ }^{\circledR}$ Intense. ${ }^{29}$ Patients were satisfied with the results; however, they had to undergo injections every 6-12 months to maintain the esthetic outcomes. ${ }^{29}$

\section{Tolerability and safety of Belotero ${ }^{\circledR}$ Intense Pain}

In the 48-week split-face RCT, pain after injection was lower with Belotero ${ }^{\circledR}$ Intense than Perlane ${ }^{\circledR}$ (3.9 vs 5.0, $P=0.01$ ), which were both lidocaine-free. ${ }^{19}$ In two patients treated for facial lipoatrophy, pain was reported to be similar between Belotero ${ }^{\circledR}$ Basic/Balance and Belotero ${ }^{\circledR}$ Intense. ${ }^{29}$

\section{Adverse events}

Similar to what was reported with Belotero ${ }^{\circledR}$ Basic/Balance, the majority of the events related to Belotero ${ }^{\circledR}$ Intense treatment were injection-site AEs of mild or moderate intensity.

In the open-label study including 149 patients, 39 of whom received Belotero ${ }^{\circledR}$ Basic/Balance after Belotero ${ }^{\circledR}$ Intense, $85.9 \%$ of patients reported AEs immediately after injection, most of which were related to the procedure. ${ }^{28}$ This incidence dropped to $12.8 \%$ at 2 weeks and $3.4 \%$ at 12 weeks, illustrating the short-term nature of these events. ${ }^{28}$

Most common AEs were erythema, ${ }^{19,28,29}$ edema, ${ }^{19,28,29}$ pain, ${ }^{19,28,29}$ bruising, ${ }^{19,28}$ (which could be severe ${ }^{19}$ ), and induration, ${ }^{19,28}$ with a reported incidence ranging from $21.5 \%$ to $63.8 \%{ }^{28}$ Mild-to-moderate tenderness, nodules, and pruritus have also been reported. ${ }^{19}$

No induration, nodules, or granulomas were observed in the two patients treated for HIV-associated facial lipoatrophy. ${ }^{29}$

\section{Long-term tolerability}

Long-term clinical data regarding the tolerability of Belotero ${ }^{\circledR}$ Intense are currently lacking. In the split-face RCT, both Belotero ${ }^{\circledR}$ Intense and Perlane ${ }^{\circledR}$ were well tolerated during the 12 months following a single injection. ${ }^{19}$ In the largescale open-label study, tolerability was rated as poor in only one case $(0.7 \%)$ and was considered as excellent or good at 3 months in $96.6 \%$ of cases. ${ }^{28}$

\section{Patients' and investigators' satisfaction with Belotero ${ }^{\circledR}$ Intense}

The positive findings regarding the performance (mean wrinkle depth and WSRS) and safety of Belotero ${ }^{\circledR}$ Intense in the 48-week RCT were confirmed by the patient's satisfaction rate. ${ }^{19}$ A higher percentage of patients were satisfied with Belotero ${ }^{\circledR}$ Intense than Perlane ${ }^{\circledR}$ at $24(62 \%$ vs $51 \%, P=0.002)$ and 48 weeks ( $43 \%$ vs $33 \%, P=0.005)$. For Belotero ${ }^{\circledR}$ Intense, the patient's satisfaction at 48 weeks was still higher than at baseline before injection (43\% vs 29\%), whereas satisfaction came back to baseline value with Perlane ${ }^{\circledR}$ (33\% vs $31 \%$ ). In accordance with these findings, $80 \%$ of patients would repeat their treatment with Belotero ${ }^{\circledR}$ Intense, vs $65 \%$ of patients with Perlane ${ }^{\circledR} .{ }^{19}$

Short-term satisfaction rates were even higher. In the 12-week open-label study, the large majority of investigators and patients $(90.6 \%$ and $94 \%)$ rated their satisfaction as excellent or good. ${ }^{28}$ In particular, mean investigators' ratings of syringe handling, injection pressure, filler dispersal, and plasticity ranged from 1.50 to 1.88 ( 1 being excellent, 2 being good). ${ }^{28}$

\section{Belotero ${ }^{\circledR}$ Volume}

Belotero ${ }^{\circledR}$ Volume has been used for treating facial lipoatrophy, associated with either HIV ${ }^{21}$ or age, ${ }^{46}$ or more generally facial soft-tissue volume loss. ${ }^{47}$

\section{Performance of Belotero ${ }^{\circledR}$ Volume}

In patients with HIV-associated lipoatrophy $(n=10)$, the performance of Belotero ${ }^{\circledR}$ Volume has been objectively assessed using MRI. ${ }^{21}$ One month after injection, the volume of the filler had increased by $331 \%$ on average $(P<0.0001)$, and no volume reduction was observed at 12 months. Skin thickness and tissue vascularization also increased during the first 6 months of the study $(P=0.01)$.

Injection of Belotero ${ }^{\circledR}$ Volume in 20 patients with agerelated mid face lipoatrophy ${ }^{46}$ and 56 patients with facial volume $\operatorname{loss}^{47}$ led to a marked decrease in the severity of volume loss, which persisted for at least 6 months and for up to 18 months (Figure 5 presents results in the cheeks).

According to GAIS scores, all patients considered themselves, or were considered by the investigators, as "improved" to "very much improved" at 6 months, ${ }^{46,47}$ and even 12 months (Table 4). ${ }^{21}$

\section{Tolerability and safety of Belotero ${ }^{\circledR}$ Volume Pain}

Pain of mild-to-moderate intensity was reported immediately after injection in six out of 20 patients $(30 \%)$ treated with Belotero ${ }^{\circledR}$ Volume. ${ }^{46}$

\section{Adverse events}

Mild-to-moderate injection-site AEs were the most common AEs reported with Belotero ${ }^{\circledR}$ Volume, with an incidence of $20 \%$ (two out of 10 patients), ${ }^{21} 25 \%$ (14 out of 56 patients), ${ }^{47}$ 


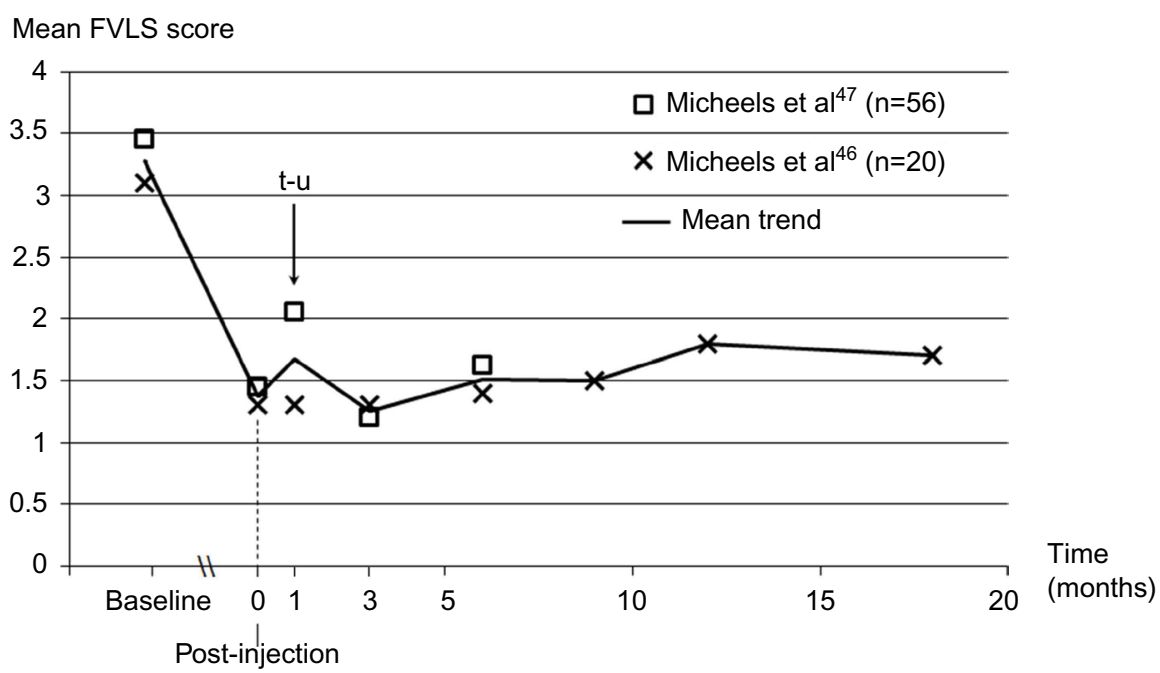

Figure 5 Long-term change in facial volume loss (cheeks) with Belotero ${ }^{\circledR}$ Volume treatment based on the investigators' rating on the Facial Volume Loss Scale.

Notes: The difference from baseline was tested by Micheels et $\mathrm{al}^{46}$ and was statistically significant at each time point $(P<0.000 \mathrm{I})$. The mean trend shows the average scores when pooling data from the two studies. In Micheels et al's study, ${ }^{47}$ other facial areas than the cheeks were assessed. Only results for cheeks are presented here for comparison with Micheels et al. ${ }^{46}$ Assessments were performed at baseline, the day following the injection (ie, post-injection), and then at I, 3 , and 6 months. Touch-up at I month was performed in two out of 56 patients (3.6\%). ${ }^{47}$ In Micheels et al's study, ${ }^{46}$ assessments were performed at baseline, immediately post-injection, and then at I, $3,6,9$, and 12 months, with an optional follow-up at 18 months $(n=I I)$. Touch-up was performed in two out of 20 patients ( $10 \%$, timing not provided). ${ }^{46}$ Baseline is before the injection. Reproduced from Micheels P, Ascher B, Beilin G, Elias B, Rummaneethorn P, Sattler G. Evaluation clinique de l'efficacité et l'innocuité d'un acide hyaluronique volumateur de technologie $\mathrm{CPM}^{\circledR}$ pour le traitement de multiples zones du visage [Clinical evaluation of the efficacy and safety of a hyaluronic acid volumizer with $\mathrm{CPM}^{\circledR}$ technology for the treatment of multiple facial areas]. Réal Thér Dermato-Vénérol. 2014;235(3):2-8. French. ${ }^{47}$ Micheels P, Vandeputte J, Kravtsov M. Treatment of age-related midface atrophy by injection of cohesive polydensified matrix hyaluronic acid volumizer. J Clin Aesthet Dermatol. 20I5;8(3):28-34.46 Copyright @20I5 Matrix Medical Communications. All rights reserved. ${ }^{46}$

Abbreviations: FVLS, Facial Volume Loss Scale; t-u, touch-up allowed.

or up to $65 \%$ (13 out 20 patients). ${ }^{46}$ The most common AEs after injection were erythema, ${ }^{21,46,47}$ pain, and edema. ${ }^{46,47}$ Edema persisted for up to 3 months in four cases overall. ${ }^{46,47}$ Of these four cases, one patient experienced persistent edema in the orbital margin (following injection of $1.9 \mathrm{~mL}$ of product on both sides), which was successfully treated with a hyaluronidase injection. ${ }^{46}$ According to the authors, this event could have been caused by inaccurate injection (too close to the orbital margin), inaccurate remodeling (moving the product too close to the orbital margin), and lymphatic spread or reactive edema. ${ }^{46}$ Cases of transient bruising, itching, and induration have also been reported. ${ }^{46,47}$

\section{Patients' and investigators' satisfaction with Belotero ${ }^{\circledR}$ Volume}

In accordance with the MRI findings obtained in ten patients with HIV-associated lipoatrophy, patient's satisfaction significantly improved between baseline and 12 months $(+15.5 \%$, $P=0.04) .{ }^{21}$ The level of satisfaction was excellent in patients treated for age-related facial lipoatrophy, with $95 \%$ (19 out of 20 ) and $100 \%$ (eleven out of eleven) of patients being satisfied 12 and 18 months after injection. ${ }^{46}$ In addition, the investigators reported that the volumizing effect was instantaneous and similar to $(50 \%)$ or better than $(50 \%)$ other volumizers such as Juvéderm ${ }^{\circledR}$ Voluma, Restylane ${ }^{\circledR}$ SubQ, Radiesse ${ }^{\circledR}$, and Teosyal ${ }^{\circledR}$ Deep. ${ }^{47}$

\section{Discussion}

The clinical data on the Belotero ${ }^{\circledR}$ dermal fillers were reviewed to analyze the performance, tolerability, and safety of these fillers for soft-tissue augmentation and rejuvenation.

The best level of evidence concerns the performance of Belotero ${ }^{\circledR}$ Basic/Balance, which has been compared to collagen and to other HA fillers in the treatment of NLFs, in split-face RCTs. Belotero ${ }^{\circledR}$ Basic/Balance was found to be superior to collagen $^{35,36}$ and to result in a greater reduction of wrinkle depth than Restylane ${ }^{\circledR} 4$ weeks after injection. ${ }^{9,37}$ At 12 months, esthetic results were relatively similar between HA fillers. ${ }^{37}$ The performance of Belotero ${ }^{\circledR}$ Basic/Balance, which was demonstrated in Caucasian patients in the treatment of NLFs, was confirmed in patients with Fitzpatrick skin types IV, $\mathrm{V}$, and $\mathrm{VI}^{34}$ and in the treatment of infraorbital hollow and tear trough. ${ }^{40,41}$ An improvement of at least 1 point on the severity scale, which is considered as a clinically relevant outcome, can be expected in $\sim 80 \%$ of patients, $1-6$ months after injection, ${ }^{33,40,41}$ and persistence of treatment effect for 8-12 months. ${ }^{35,37,40,41}$

Belotero ${ }^{\circledR}$ Intense was also found to be successful in facial treatments, with good level of evidence obtained for NLF filling. ${ }^{19,28}$ When compared to Perlane ${ }^{\circledR}$, patient's satisfaction was higher with Belotero ${ }^{\circledR}$ Intense, possibly due to the slightly better esthetic results and lower pain. ${ }^{19}$

Regarding Belotero ${ }^{\circledR}$ Volume, a convincing MRI study on the treatment of HIV-associated facial lipoatrophy showed no 
reduction in the volume of $\mathrm{HA}$ at 12 months,${ }^{21}$ and investigations to further support this filler are ongoing. Further clinical studies are needed to assess the performance of Belotero ${ }^{\circledR}$ Hydro and Soft. In the case of Belotero ${ }^{\circledR}$ Volume and Hydro, the lack of published clinical evidence can be explained by the later introduction of these products on the market compared to Belotero ${ }^{\circledR}$ Basic/Balance.

Regardless of the type of Belotero ${ }^{\circledR}$ dermal filler, the most common adverse effects noticed were mild-to-moderate erythema, edema, and hematoma, most of which resolved within a few days or weeks and were related to the injection procedure rather than the filler itself. No persisting nodules, granulomas, and tissue necrosis due to intravascular injection have been reported in long-term safety reports. ${ }^{26,35,38}$ When injected into the abdominal skin, Belotero ${ }^{\circledR}$ products (Basic/Balance and Intense) were found to induce the least immunological reaction compared to other fillers (biphasic fillers, monodensified monophasic fillers, or collagen). ${ }^{48}$ Altogether, these findings suggest a good long-term tolerability of these fillers. ${ }^{10}$

HA is increasingly used for esthetic purposes due to its excellent water-binding capacity. ${ }^{49}$ With a dry weight of $5.5 \mathrm{mg} / \mathrm{mL}{ }^{49}$ its filling capacity is higher than the one of collagen (dry weight $65 \mathrm{~g} / \mathrm{mL}$ ), the latter no longer playing a role in clinical practice. However, differences exist between HA fillers regarding their viscoelastic properties (cohesivity, elasticity, viscosity, and plasticity), which describe how the filler deforms, flows, and behaves. ${ }^{50}$ Since the natural elasticity or tension of the skin tends to deform and flatten out the implant,${ }^{50}$ the viscoelastic properties determine the clinical effects of the filler. ${ }^{5,11,50}$

Belotero $^{\circledR}$ dermal fillers present with a unique balance between elasticity and viscosity, which correlates with the soft, flowing qualities of these fillers. ${ }^{17,51}$ When compared to other fillers such as Restylane ${ }^{\circledR}$, Juvéderm ${ }^{\circledR}$ Ultra 3/Ultra 4/ Voluma, or Teosyal ${ }^{\circledR}$ Deep Line/Ultra Deep, the Belotero ${ }^{\circledR}$ fillers provide a "smoother" esthetic effect. ${ }^{17,51}$

This effect is due to the homogeneous tissue distribution of the filler intradermally, as demonstrated on ultrasound images $^{22-24}$ and by histology. ${ }^{11,12,23,24,48}$ When injected into the middle layer of the reticular dermis, Belotero ${ }^{\circledR}$ Basic/ Balance (monophasic polydensified gel) distributes uniformly throughout the reticular dermis, filling the spaces between collagen bundles. ${ }^{12}$ In contrast, Restylane ${ }^{\circledR}$ (biphasic gel) showed large pools of HA in the mid dermis and subcutaneous tissue, while Juvéderm ${ }^{\circledR}$ Ultra 3 (monodensified monophasic gel) remained within the dermis but retained aggregation characteristics. ${ }^{12}$ Scanning electron microscopy was used to study the localization and ultrastructure of the HA polymers in dermal fillers. ${ }^{52}$ The HA polymers appeared as a fibrous network structure suspended in an aqueous medium. Belotero ${ }^{\circledR}$ Balance presented as the filler with the most uniform distribution, followed by Juvéderm ${ }^{\circledR}$ Ultra and Restylane ${ }^{\circledR}$. Whereas no discrete particles could be detected in Belotero ${ }^{\circledR}$ Balance and Juvéderm ${ }^{\circledR}$ Ultra, Restylane ${ }^{\circledR}$ showed particles of irregular size embedded in a diffuse network. ${ }^{52}$

The viscoelastic properties of Belotero ${ }^{\circledR}$ Basic/Balance allow injecting the filler into the superficial layer of the reticular dermis, by using the "blanching technique" without producing any Tyndall effect. ${ }^{24}$ This technique is characterized by the temporary blanching of the injected area (for $\sim 10$ minutes), due to the transparent appearance of the gel as a result of its proximity to the skin surface. ${ }^{24} \mathrm{~A}$ very close multipuncture approach is required, with a $30 \mathrm{G}$ needle or finer, rather than the conventional retrograde approach used for HA fillers injected in the mid and deep dermis. Homogeneous tissue integration of HA, along with mild-to-no inflammation, was seen after injection of small volume of Belotero $^{\circledR}$ Basic/Balance $(0.2 \mathrm{~mL})$ using this technique. ${ }^{23,24}$ Thanks to the small volume of filler injected per wrinkle, many areas can be treated with high effectiveness, high patient satisfaction, and little-to-no risk of Tyndall effects. ${ }^{24}$

Another distinct feature of the Belotero ${ }^{\circledR}$ dermal fillers is the presence of high-density and low-density zones in the gel, as a result of the $\mathrm{CPM}^{\circledR}$ technology. ${ }^{16}$ Similar to Restylane ${ }^{\circledR}$, Perlane ${ }^{\circledR}$, and the Juvéderm ${ }^{\circledR}$ range of products, the HA in Belotero $^{\circledR}$ dermal fillers is crosslinked using 1,4-butanediol diglycidyl ether. However, the Belotero ${ }^{\circledR}$ products differ from most other HA fillers by the addition of another crosslinking step which stretches the matrix obtained during the first step and adds more HA strands, thereby continuing the crosslinking process without the addition of further 1,4-butanediol diglycidyl ether. As a result, the matrix combines higher and lower crosslinking densities of HA. This characteristic allows the filling of deeper but also smaller, finer wrinkles, ${ }^{37}$ contributing to the homogeneous intradermal distribution of the material. ${ }^{3,11,53}$ In the meantime, the cohesivity of the matrix allows the gel to stay intact.

Clinical data indicate that treatment longevity is similar between HA fillers, with similar fold severity scores obtained with Belotero ${ }^{\circledR}$ Basic/Balance, Restylane ${ }^{\circledR}$, and Juvéderm ${ }^{\circledR}$ Ultra 3 at 12 months (1.5-1.6), ${ }^{37}$ and with Belotero ${ }^{\circledR}$ Intense and Perlane ${ }^{\circledR}$ at 48 weeks (ie, 11 months; $2.7-2.8$ ). ${ }^{19}$ These findings are reinforced by in vitro investigations, showing that Belotero $^{\circledR}$ is similarly ${ }^{16}$ or less $^{54}$ degraded by hyaluronidase 
than other HA fillers. The clinical outcomes at 6,12 , or 18 months are more meaningful, since short-term outcomes at 2-4 weeks may be confounded by the edema and bruising caused by the procedure.

The viscoelastic properties of the fillers affect not only the performance and longevity of treatment but also the tolerability and safety of the products. The viscoelastic properties of Belotero ${ }^{\circledR}$ dermal fillers allow for a low and even injection pressure, which is thought to decrease pain and other AEs. ${ }^{49}$ However, pain during and immediately after injection remains a common side effect of any HA filler. To address this issue, the Belotero ${ }^{\circledR}$ dermal fillers - except Belotero ${ }^{\circledR}$ Hydro - now come with or without lidocaine. In a split-face trial in 29 patients, the addition of lidocaine led to a 3-point decrease in the average pain score, on a 10-point scale. ${ }^{32}$ Of note, the density of nociceptors is higher in the upper dermis compared to the deeper dermis, which could explain the pain that patients tend to experience with the blanching technique. ${ }^{32}$

In general terms, Belotero ${ }^{\circledR}$ dermal fillers showed a safety profile that was slightly better than collagen ${ }^{36}$ and relatively similar to other HA fillers tested in split-face RCTs. ${ }^{9,19,37}$

The adverse effects reported with Belotero ${ }^{\circledR}$ dermal fillers are those commonly seen with other fillers (erythema, edema, ecchymosis). ${ }^{38}$ Bruising tends to be more common when treating areas with a high density on blood vessels. Despite being considered as a potential side effect, ${ }^{27}$ no Tyndall effect has been reported with Belotero ${ }^{\circledR}$ dermal fillers, including in the large-scale studies ( $>90$ patients). ${ }^{28,33,35-37,39}$ The use of hyaluronidase to treat an $\mathrm{AE}$ was reported in only one patient treated with Belotero ${ }^{\circledR}$ Volume and who experienced persistent edema in the orbital margin. ${ }^{46}$ This event could have been caused by inaccurate injection, inaccurate remodeling, or lymphatic spread.

The relatively high incidence of nodules reported by Narins et al in their 6-month RCT (33.1\% of patients vs $55.1 \%$ with collagen; Table 4$)^{36}$ contrasts with the absence of nodules after re-treatment and touch-ups during the 2-year follow-up, ${ }^{35}$ and the absence of nodules in the majority of published studies. Reasons for these findings are unclear. They may be due to the inconsistent definition of nodules and granulomas in the literature, ${ }^{55}$ or to different injection techniques, since nodules are frequently caused by an incorrect technique.

Repeated injections of Belotero ${ }^{\circledR}$ dermal fillers seem to be well tolerated..$^{26,29,35,40,44}$ These findings are consistent with the measurement of HA antibodies, suggesting little potential for immunogenic reactions following Belotero ${ }^{\circledR}$ injection, ${ }^{35}$ and with histological findings. ${ }^{11,23,24,48}$ When injected into the abdominal skin, Belotero ${ }^{\circledR}$ products (Basic/Balance and Intense) induced a histomorphological reaction free of inflammation, whereas other dermal fillers (Restylane ${ }^{\circledR}$, Perlane $^{\circledR}$, Juvéderm ${ }^{\circledR}$ Ultra 3 and 30 HV, Surgiderm ${ }^{\circledR} 24$ XP and 30, Teosyal ${ }^{\circledR}$ Global Action and Deep Lines) provoked varying, predominantly slight-to-moderate degrees of chronic inflammation. ${ }^{48}$ Nevertheless, these data were collected over a 30-day period. Long-term tolerability data, especially regarding the risk of delayed immune-related AEs, ${ }^{56,57}$ are therefore needed.

The practitioners showed high levels of satisfaction with Belotero ${ }^{\circledR}$ Basic/Balance, ${ }^{36}$ Intense, ${ }^{28}$ and Volume, ${ }^{46}$ in particular regarding the ease of use of these fillers. ${ }^{28,36}$ Similarly, the patients' satisfaction rate with the different Belotero $^{\circledR}$ dermal fillers ranged from $60 \%$ to $94 \%,{ }^{19,28,36,46}$ with a majority of patients returning for further treatments. ${ }^{26,38}$ These satisfaction rates are likely explained by the esthetic effects of the fillers combined with their good tolerability.

Clinical evidence indicates sustainable esthetic effects, good safety profile, and long-term tolerability of the Belotero $^{\circledR}$ dermal fillers, with the best level of evidence supporting Belotero ${ }^{\circledR}$ Basic/Balance and Intense. Treatment effects are immediate and last for $\sim 6-12$ months, depending on the filler. Patient's satisfaction was shown to be high across fillers, which could be explained by the excellent tissue integration of the material combined with a good safety profile and reasonable level of pain during and immediately after injection. There were no reports of SAEs related to the product or the injection procedure, and no reports of Tyndall effect. Belotero ${ }^{\circledR}$ Basic/Balance and Soft offer the possibility of injecting in the superficial layer of the dermis using the blanching technique. More studies would be needed on the Belotero ${ }^{\circledR}$ dermal fillers more recently introduced on the market.

\section{Acknowledgments}

Merz Pharmaceuticals GmbH, Frankfurt am Main, Germany, provided financial support for the manuscript preparation and gratefully acknowledges Scinopsis Medical Writing for their assistance. None of the authors received any financial support for the writing of this manuscript. Written patient consent was obtained for the use of the photos in Figure 3.

\section{Disclosure}

Dr Prasetyo is a consultant and sits on advisory boards for Allergan and Merz Pharmaceuticals, and has received grants, honoraria, and travel support for giving lectures from 
Allergan, GlaxoSmithKline, Merck Sharp \& Dohme, and Merz Pharmaceuticals. Dr Prager is a lecturer and researcher for Allergan, Beiersdorf, Cynosure, Galderma, Lumenis, Merz Pharmaceuticals, and Skinceuticals. Dr Rubin is a consultant for Merz Pharmaceuticals. Dr Nikolis is a consultant and speaker for Allergan, Galderma, and Merz Pharmaceuticals. Dr Moretti has no conflicts of interest to declare in this work.

\section{References}

1. Brandt FS, Cazzaniga A. Hyaluronic acid gel fillers in the management of facial aging. Clin Interv Aging. 2008;3(1):153-159.

2. Carruthers J, Cohen SR, Joseph JH, Narins RS, Rubin M. The science and art of dermal fillers for soft-tissue augmentation. J Drugs Dermatol. 2009;8(4):335-350.

3. Palm MD. Filler frontier: what's new and heading West to the US market. Semin Cutan Med Surg. 2014;33(4):157-163.

4. International Society of Aesthetic Plastic Surgery (ISAPS). International survey on aesthetic/cosmetic procedures performed in 2013. 2014. Available from: http://www.isaps.org/Media/Default/globalstatistics $/ 2014 \% 20$ ISAPS $\% 20$ Results $\% 20 \% 283 \% 29$.pdf. Accessed September 23, 2015

5. Funt D, Pavicic T. Dermal fillers in aesthetics: an overview of adverse events and treatment approaches. Clin Cosmet Investig Dermatol. 2013; 6:295-316.

6. Daines SM, Williams EF. Complications associated with injectable soft-tissue fillers: a 5-year retrospective review. JAMA Facial Plast Surg. 2013;15(3):226-231.

7. Lorenc ZP, Fagien S, FlynnTC, Waldorf HA. Review of key Belotero Balance safety and efficacy trials. Plast Reconstr Surg. 2013;132(4 Suppl 2):33S-40S.

8. Necas J, Bartosikova L, Brauner P, Kolar J. Hyaluronic acid (hyaluronan): a review. Vet Med. 2008;53(8):397-411.

9. Prager W, Steinkraus V. A prospective, rater-blind, randomized comparison of the effectiveness and tolerability of Belotero ${ }^{\circledR}$ Basic versus Restylane ${ }^{\circledR}$ for correction of nasolabial folds. Eur J Dermatol. 2010;20(6):748-752.

10. Wollina U, Goldman A. Hyaluronic acid dermal fillers: safety and efficacy for the treatment of wrinkles, aging skin, body sculpturing and medical conditions. Clin Med Rev Ther. 2011;3:107-121.

11. Tran C, Carraux P, Micheels P, Kaya G, Salomon D. In vivo bio-integration of three hyaluronic acid fillers in human skin: a histological study. Dermatology. 2014;228(1):47-54.

12. Flynn TC, Sarazin D, Bezzola A, Terrani C, Micheels P. Comparative histology of intradermal implantation of mono and biphasic hyaluronic acid fillers. Dermatol Surg. 2011;37(5):637-643.

13. Verpaele A, Strand A. Restylane SubQ, a non-animal stabilized hyaluronic acid gel for soft tissue augmentation of the mid- and lower face. Aesthet Surg J. 2006;26(1S):S10-S17.

14. Bogdan Allemann I, Baumann L. Hyaluronic acid gel (Juvederm) preparations in the treatment of facial wrinkles and folds. Clin Interv Aging. 2008;3(4):629-634.

15. Philipp-Dormston WG, Hilton S, Nathan M. A prospective, open-label, multicenter, observational, postmarket study of the use of a $15 \mathrm{mg} / \mathrm{mL}$ hyaluronic acid dermal filler in the lips. J Cosmet Dermatol. 2014;13(2):125-134.

16. Flynn TC, Thompson DH, Hyun SH. Molecular weight analyses and enzymatic degradation profiles of the soft-tissue fillers Belotero Balance, Restylane, and Juvederm Ultra. Plast Reconstr Surg. 2013;132(4 Suppl 2):22S-32S.

17. Santoro S, Russo L, Argenzio V, Borzacchiello A. Rheological properties of cross-linked hyaluronic acid dermal fillers. J Appl Biomater Biomech. 2011;9(2):127-136.

18. Reinmüller J. Hyaluronsäure in der ästhetischen Medizin - Historie, Entwicklung, heutige Bedeutung [Hyaluronic acid in aesthetics - History, development, and today's importance]. J Dtsch Dermatol Ges. 2008;6(Supp1 2):S4-S9. German.
19. Buntrock H, Reuther T, Prager W, Kerscher M. Efficacy, safety, and patient satisfaction of a monophasic cohesive polydensified matrix versus a biphasic nonanimal stabilized hyaluronic acid filler after single injection in nasolabial folds. Dermatol Surg. 2013;39(7):1097-1105.

20. Jacobi U, Chen M, Frankowski G, et al. In vivo determination of skin surface topography using an optical 3D device. Skin Res Technol. 2004;10(4):207-214.

21. Becker M, Balague N, Montet X, Calmy A, Salomon D, Toutous-Trellu L. Hyaluronic acid filler in HIV-associated facial lipoatrophy: evaluation of tissue distribution and morphology with MRI. Dermatology. 2015;230(4):367-374.

22. Goh AS, Kohn JC, Rootman DB, Lin JL, Goldberg RA. Hyaluronic acid gel distribution pattern in periocular area with high-resolution ultrasound imaging. Aesthet Surg J. 2014;34(4):510-515.

23. Micheels P, Besse S, Flynn TC, Sarazin D, Elbaz Y. Superficial dermal injection of hyaluronic acid soft tissue fillers: comparative ultrasound study. Dermatol Surg. 2012;38(7 Pt 2):1162-1169.

24. Micheels P, Sarazin D, Besse S, Sundaram H, Flynn TC. A blanching technique for intradermal injection of the hyaluronic acid Belotero. Plast Reconstr Surg. 2013;132(4 Suppl 2):59S-68S.

25. Hasson A, Romero WA. Treatment of facial atrophic scars with Esthelis, a hyaluronic acid filler with polydense cohesive matrix (CPM). J Drugs Dermatol. 2010;9(12):1507-1509.

26. Micheels P. Esthélis, hyaluronic acid of Swiss design: first complete study of the physico-chemical characteristics and clinical trials, 24-months safety follow-up report. J Cosmet Surg Med. 2009;4(3):62-65.

27. Bezzola A, Micheels P. Esthélis, hyaluronic acid of Swiss design. First complete study on the physico-chemical characteristics and clinical trials. J Med Esthet Chir Dermatol. 2005;125:11-20.

28. Pavicic T. Efficacy and tolerability of a new monophasic, doublecrosslinked hyaluronic acid filler for correction of deep lines and wrinkles. J Drugs Dermatol. 2011;10(2):134-139.

29. Pavicic T, Ruzicka T, Korting HC, Gauglitz G. Monophasic, cohesivepolydensified-matrix crosslinking-technology-based hyaluronic acid filler for the treatment of facial lipoatrophy in HIV-infected patients. $J$ Drugs Dermatol. 2010;9(6):690-695.

30. Pavicic T, Few JW, Huber-Vorlander J. A novel, multistep, combination facial rejuvenation procedure for treatment of the whole face with incobotulinumtoxin A, and two dermal fillers - calcium hydroxylapatite and a monophasic, polydensified hyaluronic acid filler. J Drugs Dermatol. 2013;12(9):978-984.

31. Moradi A, Shirazi A, Moradi-Poehler J, Turner J, Howell DJ. A blinded, randomized, split-face pilot study of bruising and pain with hyaluronic acid for correction of perioral lines using no lidocaine, lidocaine alone, and lidocaine and epinephrine. Aesthet Surg J. 2015;35(4):443-455.

32. Prager W, Micheels P. A prospective, comparative survey to investigate practitioners' satisfaction with a cohesive, polydensified-matrix ${ }^{\circledR}$, hyaluronic acid-based filler gel with and without lidocaine for the treatment of facial wrinkles. J Cosmet Dermatol. 2015;14(2):124-129.

33. Dirting K, Lampe H, Wolters M, Prager W, Reinmüller J. Hyaluronsäurefiller zur Korrektur der Nasolabialfalten - Ergebnisse einer klinischen Studie [Hyaluronic acid filler for correction of nasolabial grooves results of a clinical study]. J Dtsch Dermatol Ges. 2008;6(Suppl 2):S10-S14. German.

34. Downie JB, Grimes PE, Callender VD. A multicenter study of the safety and effectiveness of hyaluronic acid with a cohesive polydensified matrix for treatment of nasolabial folds in subjects with Fitzpatrick skin types IV, V, and VI. Plast Reconstr Surg. 2013;132(4 Suppl 2):41S-47S.

35. Narins RS, Coleman WP 3rd, Donofrio LM, et al. Improvement in nasolabial folds with a hyaluronic acid filler using a cohesive polydensified matrix technology: results from an 18-month open-label extension trial. Dermatol Surg. 2010;36 Suppl 3:1800-1808.

36. Narins RS, Coleman WP 3rd, Donofrio LM, et al. Nonanimal sourced hyaluronic acid-based dermal filler using a cohesive polydensified matrix technology is superior to bovine collagen in the correction of moderate to severe nasolabial folds: results from a 6-month, randomized, blinded, controlled, multicenter study. Dermatol Surg. 2010;36:730-740. 
37. Prager W, Wissmueller E, Havermann I, et al. A prospective, split-face, randomized, comparative study of safety and 12-month longevity of three formulations of hyaluronic acid dermal filler for treatment of nasolabial folds. Dermatol Surg. 2012;38(7 Pt 2):1143-1150.

38. Kühne U, Imhof M, Kirchmeir M, Howell DJ. Five-year retrospective review of safety, injected volumes, and longevity of the hyaluronic acid Belotero Basic for facial treatments in 317 patients. J Drugs Dermatol. 2012;11(9):1032-1035.

39. Gregory I. A study of the clinical effectiveness of a new polydensified monophasic hyaluronic acid dermal filler. J Cosmet Surg Med. 2007;3(1):32-34.

40. Hevia O, Cohen BH, Howell DJ. Safety and efficacy of a cohesive polydensified matrix hyaluronic acid for the correction of infraorbital hollow: an observational study with results at 40 weeks. $J$ Drugs Dermatol. 2014;13(9):1030-1036.

41. Wollina U. Improvement of tear trough by monophasic hyaluronic acid and calcium hydroxylapatite. J Clin Aesthet Dermatol. 2014;7(10):38-43.

42. Gilbert E, Calvisi L. Midface and perioral volume restoration: a conversation between US and Italy. J Drugs Dermatol. 2014;13(1): $67-74$.

43. Hamilton RG, Strobos J, Adkinson NF Jr. Immunogenicity studies of cosmetically administered nonanimal-stabilized hyaluronic acid particles. Dermatol Surg. 2007;33 Suppl 2:S176-S185.

44. Succi IB, da Silva RT, Orofino-Costa R. Rejuvenation of periorbital area: treatment with an injectable nonanimal non-crosslinked glycerol added hyaluronic acid preparation. Dermatol Surg. 2012;38(2):192-198.

45. Micheels P. Fortélis extra resorbable and non-surgical volumising implant of Swiss conception. J Cosmet Surg Med. 2011;6(1): 30-34.

46. Micheels P, Vandeputte J, Kravtsov M. Treatment of age-related midface atrophy by injection of cohesive polydensified matrix hyaluronic acid volumizer. J Clin Aesthet Dermatol. 2015;8(3):28-34.

47. Micheels P, Ascher B, Beilin G, Elias B, Rummaneethorn P, Sattler G. Evaluation clinique de l'efficacité et l'innocuité d'un acide hyaluronique volumateur de technologie $\mathrm{CPM}^{\circledR}$ pour le traitement de multiples zones du visage [Clinical evaluation of the efficacy and safety of a hyaluronic acid volumizer with $\mathrm{CPM}^{\circledR}$ technology for the treatment of multiple facial areas]. Réal Thér Dermato-Vénérol. 2014;235(3):2-8. French.
48. Taufig AZ, Szöke A, Kühnel W. A new strategy to detect intradermal reactions after injection of resorbable dermal fillers. J Ästhet Chir. 2009;2:29-36.

49. Kammerer S. Clinical study with monophasic polydensified hyaluronic acid filler. Dermatol News. 2007;11:1-4.

50. Borrell M, Leslie DB, Tezel A. Lift capabilities of hyaluronic acid fillers. J Cosmet Laser Ther. 2011;13(1):21-27.

51. Sundaram H, Cassuto D. Biophysical characteristics of hyaluronic acid soft-tissue fillers and their relevance to aesthetic applications. Plast Reconstr Surg. 2013;132(4 Suppl 2):5S-21S.

52. Flynn TC, Thompson DH, Hyun SH, Howell DJ. Ultrastructural analysis of 3 hyaluronic acid soft-tissue fillers using scanning electron microscopy. Dermatol Surg. 2015;41 Suppl 1:S143-S152.

53. Sundaram H, Fagien S. Cohesive polydensified matrix hyaluronic acid for fine lines. Plast Reconstr Surg. 2015;136(5 Suppl):149S-163S.

54. Rao V, Chi S, Woodward J. Reversing facial fillers: interactions between hyaluronidase and commercially available hyaluronic-acid based fillers. J Drugs Dermatol. 2014;13(9):1053-1056.

55. Lee SK, Kim HS. Recent trend in the choice of fillers and injection techniques in Asia: a questionnaire study based on expert opinion. $J$ Drugs Dermatol. 2014;13(1):24-31.

56. Alijotas-Reig J, Fernandez-Figueras MT, Puig L. Inflammatory, immune-mediated adverse reactions related to soft tissue dermal fillers. Semin Arthritis Rheum. 2013;43(2):241-258.

57. Bitterman-Deutsch O, Kogan L, Nasser F. Delayed immune mediated adverse effects to hyaluronic acid fillers: report of five cases and review of the literature. Dermatol Rep. 2015;7(5851):12-14.

58. Day DJ, Littler CM, Swift RW, Gottlieb S. The wrinkle severity rating scale: a validation study. Am J Clin Dermatol. 2004;5(1):49-52.

59. Ascher B, Coleman S, Alster T, et al. Full scope of effect of facial lipoatrophy: a framework of disease understanding. Dermatol Surg. 2006;32(8):1058-1069.

60. Carruthers J, Flynn TC, Geister TL, et al. Validated assessment scales for the mid face. Dermatol Surg. 2012;38(2 Spec No.):320-332.

61. Flynn TC, Carruthers A, Carruthers J, et al. Validated assessment scales for the upper face. Dermatol Surg. 2012;38(2 Spec No.):309-319.

62. Narins RS, Carruthers J, Flynn TC, et al. Validated assessment scales for the lower face. Dermatol Surg. 2012;38(2 Spec No.):333-342.

63. Hirmand H. Anatomy and nonsurgical correction of the tear trough deformity. Plast Reconstr Surg. 2010;125(2):699-708.
Clinical, Cosmetic and Investigational Dermatology

\section{Publish your work in this journal}

Clinical, Cosmetic and Investigational Dermatology is an international, peer-reviewed, open access, online journal that focuses on the latest clinical and experimental research in all aspects of skin disease and cosmetic interventions. This journal is included on PubMed. The manuscript management system is completely online

\section{Dovepress}

and includes a very quick and fair peer-review system, which is all easy to use. Visit http://www.dovepress.com/testimonials.php to read real quotes from published authors 